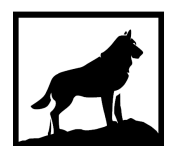

Michigan Technological

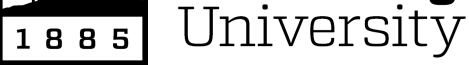

Michigan Technological University Digital Commons @ Michigan Tech

\title{
A CLUSTER ANALYSIS OF SOCIAL MEDIA USE IN THE ANGLOPHONE CRISIS IN CAMEROON: A CASE STUDY OF FACEBOOK POSTS.
}

Neh Claudia Soh

Michigan Technological University, nsoh@mtu.edu

Copyright 2020 Neh Claudia Soh

Recommended Citation

Soh, Neh Claudia, "A CLUSTER ANALYSIS OF SOCIAL MEDIA USE IN THE ANGLOPHONE CRISIS IN CAMEROON: A CASE STUDY OF FACEBOOK POSTS.", Open Access Master's Thesis, Michigan Technological University, 2020.

https://doi.org/10.37099/mtu.dc.etdr/999 
A CLUSTER ANALYSIS OF SOCIAL MEDIA USE IN THE ANGLOPHONE CRISIS IN CAMEROON: A CASE STUDY OF FACEBOOK POSTS.

By

Neh Claudia Soh

\begin{abstract}
A THESIS
Submitted in partial fulfillment of the requirements for the degree of MASTER OF SCIENCE

In Rhetoric, Theory and Culture
\end{abstract}

MICHIGAN TECHNOLOGICAL UNIVERSITY

2020

(C) 2020 Neh C. Soh 
This thesis has been submitted in partial fulfillment of the requirements for the Degree of MASTER OF SCIENCE in Rhetoric, Theory and Culture.

Department of Humanities

Thesis Advisor: Dr. Karla Kitalong

Committee Member: Dr. Marika Seigel

Committee Member: Dr. Ramon Fonkoué

Department Chair: Dr. Patricia Sotirin 


\section{Dedication}

To my sweet and supportive mom, Mrs. Amayaba Soh Matilde, and God Almighty. 


\section{Table of Contents}

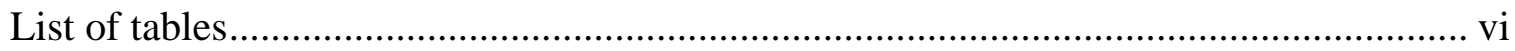

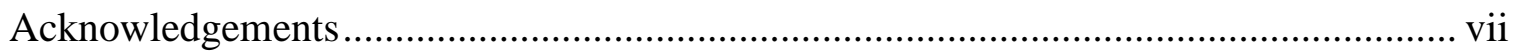

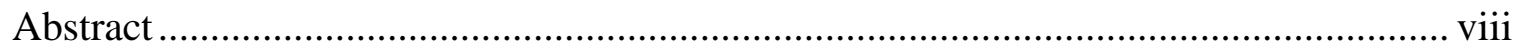

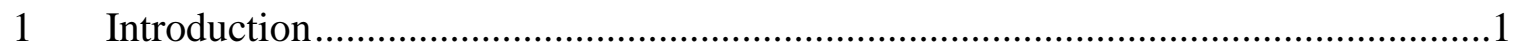

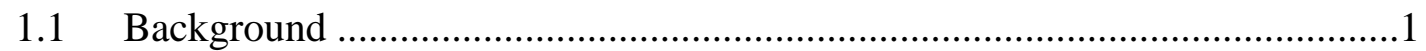

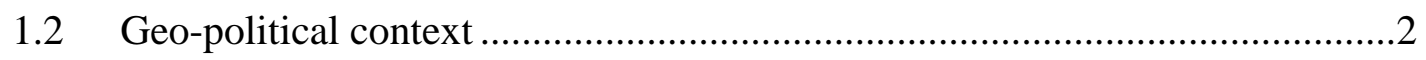

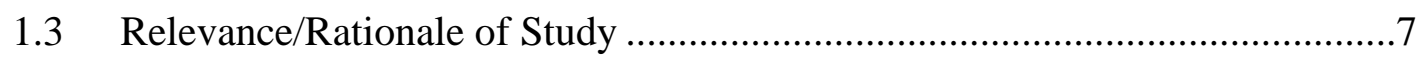

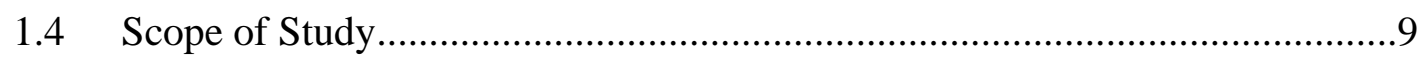

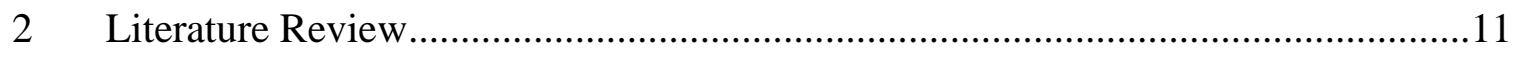

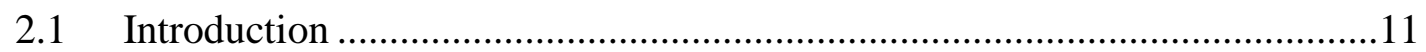

2.2 Brief Overview of Scholarship on Cluster Analysis .....................................11

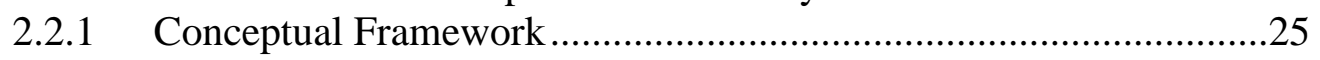

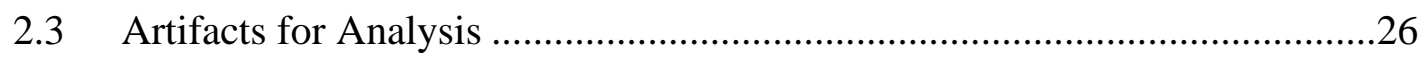

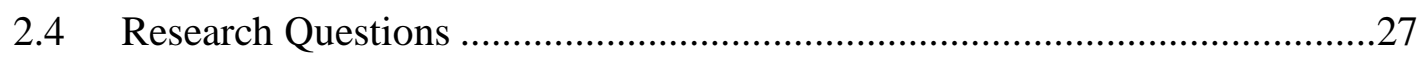

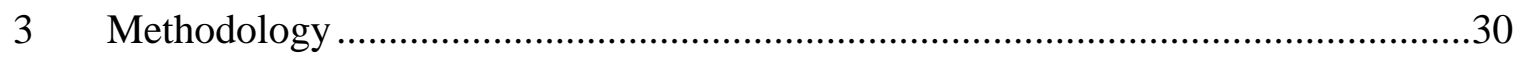

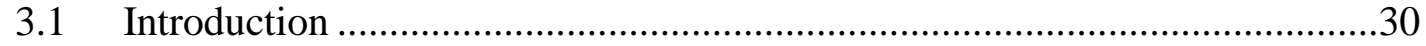

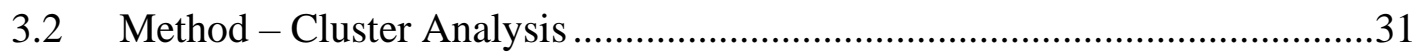

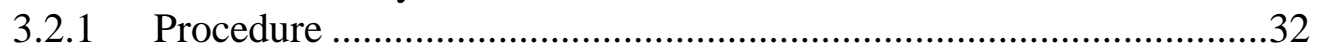

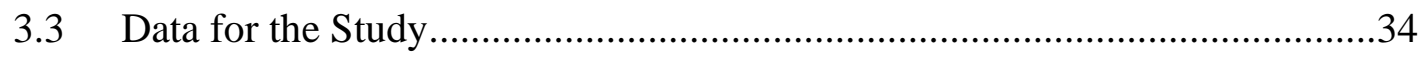

3.3.1 Description of Artifact 1: President Paul Biya's Facebook Posts......35

3.3.2 Description of Artifact 2: Activist Mark Bareta's Facebook Posts ..40

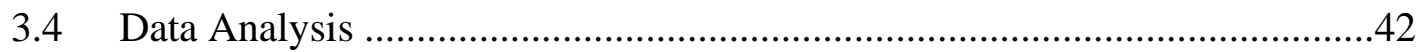

3.4.1 Mark Bareta's Facebook Posts.........................................................49

3.4.2 Visual elements of artifacts.............................................................53

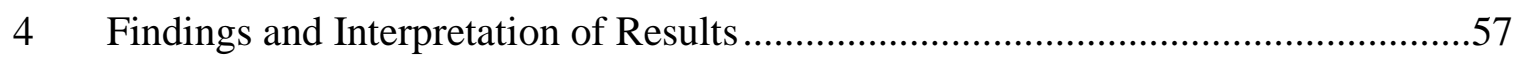

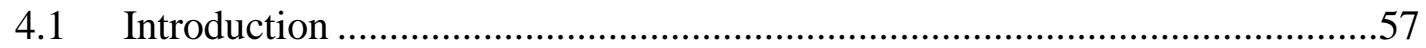

4.2 Answering Research Questions..............................................................57

4.2.1 RQ1. Narratives from president Biya's Rhetoric..............................57

4.2.2 RQ1. Narratives from activist, Bareta's Rhetoric ..............................59

4.2.3 RQ2. What do these Narratives tell us about the Actors' Motives?.60 


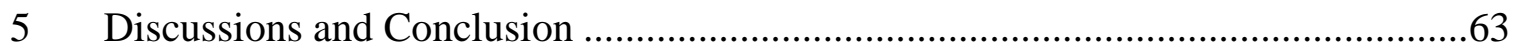

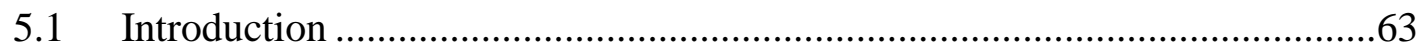

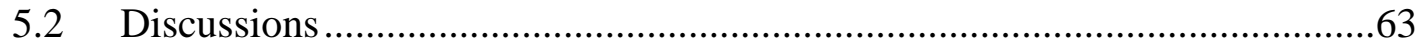

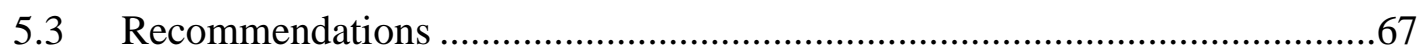

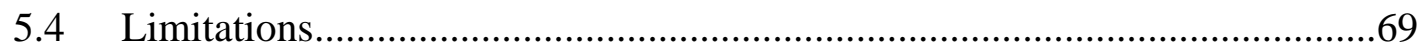

5.5 Direction for Further Research............................................................ 70

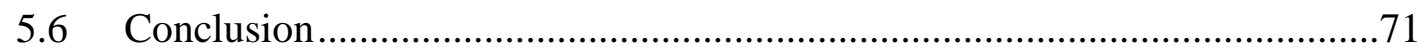

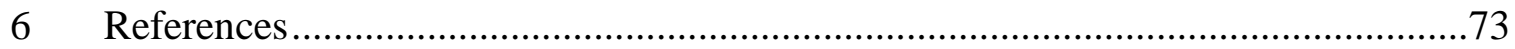




\section{List of tables}

Table 1. Summary description of president Biya's and Bareta's Facebook Posts............40

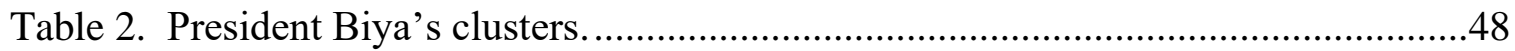

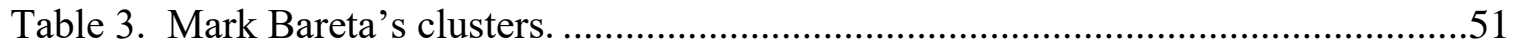




\section{Acknowledgements}

First, I want to express my gratitude to my advisor, Dr. Karla Kitalong for her mentoring. Dr. Kitalong is friendly, welcoming, helpful, and understanding. Her openness, and the jokes she'll throw around during our one-on-one meetings in her office was a source of energy and optimism for completing this thesis. The promptness with which Dr. Kitalong responds to her mentee's queries is beyond my understanding. It is the promptness with which Dr. Kitalong responded to my questions, doubts, and anxieties in the course of my research that increased by motivation to keep on keeping on despite some challenges encountered during the early stages of my research. Her visual theory class remains one of my great courses and was also very helpful in looking at some visual elements in the artifacts analyzed in this research work. I was so pleased that transitioning to online instruction following the outbreak of COVID-19 did not affect our work ethic as we still regularly met on ZOOM. Thank you so much Dr. Kitalong.

Second, I very much appreciate my committee members, Dr. Marika Seigel and Dr. Ramon Fonkoué for their feedback and apt suggestions on my work. Dr. Seigel, I am proud I took your methods class on rhetorical analysis and criticism. It is this class that propelled me into doing research that focused on Cluster Analysis as method of rhetorical criticism. The lessons learned in this class remain ingrained into my mind. I am happy I took this class. The string feedback and suggestions you made on my work transformed my thoughts on important aspects in my research. Also, I am so thankful that you were not only my professor, but also my professional coach and mentor in composition pedagogy. The lessons you taught me, the advice on succeeding as a teacher, plus the mindset of a thoughtful and responsive instructor you instilled into me continue to define my professional outlook. Thank you too, Dr. Fonkoué for your time since I joined the department. I appreciate the fact that you made time to run through some of my work during your office hours whenever I came for feedback on my writing. I am glad this is something the department of humanities encourages - that is, to have at least another mind glance through a piece of writing for feedback. Dr. Fonkoué, your book, Nation Without Narration: History, Memory and Identity in Postcolonial Cameroon" was a helpful resource particularly in thinking through chapter 1 of my thesis.

Thirdly, I am grateful to the department of humanities for offering me the opportunity to study, work, and grow my academic and professional ethics. The graduate teaching assistantship was invaluable to attaining my academic and career goals in the department. As I pursue my Ph.D. starting in Fall 2020 at another university, I take with me the lessons learned during my time at this department.

Lastly, I sincerely acknowledge my mental, moral, and spiritual support received from my lovely mom, Mrs. Amayaba Soh Matilde. The prayers and blessings you sent to me on phone helped reduce the thousands of miles that separate us and were a source of strength and encouragement. My siblings were also supportive and encouraging by sustaining the family bond that bind us together through heart warming conversations. 


\section{Abstract}

This thesis applies a method of rhetorical criticism - cluster analysis - to explore the different narratives on and about the Anglophone crisis in Cameroon by two prominent rhetors involved in the crisis. The artifacts in the study were Facebook posts published by Cameroon's president, Paul Biya, and a prominent Anglophone activist, Mark Bareta. The thesis set out to answer two research questions. The first question focused on the descriptive narratives that emerge from the rhetors in the crisis; the second question focused on the rhetors' motives. The different narratives that emerged showed that Cameroon's president pushed the narratives of "national unity" and "peace", indicating his intentions to persuade Cameroonians, particularly those in the two English speaking regions of the country, to focus on a united country. On the other hand, the prominent Anglophone activist focused his rhetoric on the narrative of secession, aligning his narrative with his intention to have Anglophone Cameroon to secede. The narratives and motives emerged from examining key terms (god terms and devil terms) plus the terms that cluster around the god terms and devil terms respectively. Trends significant to this research, recommendations on resolving the anglophone crisis, limitations of the study, and direction for further research are discussed. This thesis has contributed to rhetorical theory by applying cluster analysis as method of rhetorical criticism to social media posts (a novel area in the method's application).

Key words: cluster analysis, motives, rhetor, rhetorical criticism, narratives. 


\section{Introduction}

\subsection{Background}

Cameroon has been under political and social instability since October 2016 due to conflicts in the two English-speaking regions of the country (i.e., South West and North West regions). The conflict, also called the "Anglophone crisis," "Anglophone problem," or the "Ambazonia War," broke out following a strike action by Cameroon Anglophone lawyers and teachers in the two English-speaking regions of Cameroon calling for, among other things, an increased use of the English language in Common Law courts, and the non-amalgamation of the English subsystem of education into the French education system in the country (Maclean, 2018). This is because Common Law is practiced in the Anglophone regions while Civil Law is practiced in the French speaking regions of Cameroon. Clearly, therefore, the imposition of Civil Law tradition in the Common Law courts in the two Anglophone regions and the gradual erasure of the Anglo-Saxon sub-system in education are the main factors that led to the current crisis. But what has become a full-blown war today can be traced back to the history of independent Cameroon and to what many describe as the marginalization of Anglophone Cameroonians, who represent 17\% (4.5 million) of Cameroon's total population of 25 million (World Bank, 2018).

Over two years into the instability in Cameroon, social actors, activists, and prominent politicians (including the president of Cameroon) have taken to various social media platforms, particularly Facebook, to provide different and conflicting accounts of the crisis. At the same time, it is this perceived power of technology that led the 
government of Cameroon to shut down the internet, thus crippling the use of Facebook in the two Anglophone regions of the country for 136 days (AcessNow, 2018). Two main factors explain my interest on this topic. Firstly, the reaction from the government and my intention to examine the different narratives which different actors in the crisis created on and about the crisis. The second factor has to do with the need to suggest recommendations that could help in the resolution of the crisis. In the meantime, to better contextualize the analysis I make in this research, a look at a brief history of the geopolitical context of Cameroon is necessary.

\subsection{Geo-political context}

Cameroon has a long history of subjugation to colonial rule. The country has been administered by Germany, France, and Britain. Germany first colonized Cameroon in 1884 but lost Cameroon as a colony after World War I. Following Germany's defeat, Cameroon was placed under supervision of the League of Nations and handed over to Britain and France. France obtained a greater portion of Cameroon, which later became known as East Cameroon and then Republique du Cameroun (Republic of Cameroon). Britain took the smaller portion of Cameroon and governed it from Nigeria. This part of the country was known as British Southern Cameroons, or simply as the Southern Cameroons (The Commonwealth, 2019). The territory was made up of the Northern and southern zones. Other appellations have referred to the British territory as West Cameroon. France administered East Cameroon using French as the official language, while Britain administered the Southern Cameroons with English as its official language. 
Several political parties later emerged in both territories. In East Cameroon, the leading political party was the Union of the Peoples of Cameroon known in French as Union des Populations du Cameroun (UPC) led by Ruben Um Nyobe. French speaking Cameroon was granted independence on January 1, 1960 and became known as the Republique du Cameroun. Similarly, there were several political parties in British Southern Cameroons including Kamerun National Democratic Party (KNDP) led by John Ngu Foncha, and the Kamerun National Congress (KNC) led by Emmanuel Mbella Lifafe Endeley. These parties advocated for autonomy for Southern Cameroons, which before 1961 was administered by Britain through the National Council of Nigeria and the Cameroons headquartered in Enugu located in Nigeria. On October 1, 1961, a United Nations supervised plebiscite was held in the British Cameroons to determine the independent nature of the territory. The people of the territory were asked to vote either to gain independence by joining the Republique du Cameroun or to become independent by joining the Federal Republic of Nigeria. The Northern zone voted to join Nigeria, while the Southern zone voted to join the already independent Republic of Cameroon. The outcome of the plebiscite later led to the creation of the Federal Republic of Cameroon. This created a two-state federation - West Cameroon and East Cameroon. The name of this "new country" was the Federal Republic of Cameroon with English and French languages having equal status. However, in 1972, the first president of Cameroon, Amadou Ahidjo (1960-1982), called for a referendum in which the Federal Republic of Cameroon was again changed to the Republic of Cameroon. 
Unfortunately, the unification between French speaking Cameroon and Southern Cameroon was inadequate for both parts to efficiently recognize a dual cultural heritage and was void of equal administration. Instead, the unification was a trajectory for the Anglophones to be involved in another phase of assimilation and/or imperialism from French speaking Cameroon. Because the French speaking part of the country dominated power, the minority Anglophone territory remained marginalized (Caldwell, 2017).

According to Anyangwe (2008), French Cameroon holds Southern Cameroons forcibly under the guise of the referendum (p.2). Nonetheless, the question on whether or not French Cameroon is an imperialist power over British Cameroon is largely controversial until the current time because the UN plebiscite of 1961 never provided a third option for Southern Cameroon to be an independent territory. To an extent, it can be asserted that British Cameroon indeed was forced to join French Cameroon. The superficial peace and unity which was presumably in the Republic of Cameroon, that is both British and French speaking Cameroon which existed from 1961, has turned into a political and social instability since 2016 as Anglophone armed groups have taken up weapons fighting to secede from French Cameroon. A major grievance includes marginalization of the Anglophone cultural, educational, and legal systems by the Francophone dominated central government.

British Southern Cameroon consists of two regions (provinces), in a country of ten regions. Anglophone Cameroonians feel they are neglected because they are not adequately represented in the government (Caldwell, 2017). The feelings of neglect of the Anglophone regions by the Francophone-dominated government morphed into a civil 
war in 2017 following months of riots. Over two years into the war, Cameroon's president Paul Biya, who has been in power since 1982, called for a Major National Dialogue. The dialogue was aimed at bringing together Cameroonians of all walks of life at home and in the diaspora to dialogue a way forward out of the crisis. The dialogue was held from September 30-October 4, 2019. As outcome of the dialogue, the president ordered for a discontinuance of all pending cases in military courts involving individuals arrested from the Anglophone regions in connection with the strike actions against the government. In addition, the President freed 333 people who were in military custody on account of the Anglophone problem in the Northwest and Southwest regions of Cameroon. Also, the president granted a "special status" to the Anglophones (which is still to go into effect) in an attempt to address their grievances. The "special status," when and if it goes into effect, grants a level of autonomy to the two Anglophone regions while the central government still maintains strong control over the economic and political life of the regions. As such, the "special status" was not received with enthusiasm by the secessionists and was regarded as not efficient. This is because the "special status" consists only of the creation of a House of Chiefs, regional councils and regional assemblies for Southern Cameroons (Kindzeka, 2019). However, the "special status" does not give these institutions power to implement laws, instead, deliberations from these bodies will be sent to the National Assembly with an overwhelming francophone majority for legislative decisions. As such, Anglophone Cameroonian lawmakers were only granted deliberative powers (Kindzeka, 2019). As a result, Anglophone Cameroonians are still dependent on the centralized system of government dominated by Francophone Cameroonians. Their petition to achieve autonomy was waived. The 
Anglophones were not also granted financial independence. According to Kindzeka (2019), Anglophone activists have reacted towards the "special status" using social media platforms by referring to it as "a non-event" because their major intent is to secede completely from French speaking Cameroon.

Nonetheless, Fonkoué (2019) mentions that Cameroon's Anglophone problem is rooted in the fact that the political leaders of Cameroon did not pay heed to Cameroon's "dual heritage" and refers to this act as an "original sin" (p.8). At the same time, the conflict between Anglophones and Francophone portrays residuals of colonialism. Cameroon has two main judicial systems being implemented as mentioned earlier. Civil Law is implemented in the Francophone regions while Common Law is implemented in the Anglophone regions. This legal system conflict serves as an example of the depth of the rift between British and French Cameroon. Judges and magistrates who ruled in Anglophone courts were mostly Francophones who practiced Civil Law unlike Anglophones who practiced Common Law. This judicial practice which was practiced for long was not countered until recently in 2016 when Anglophone lawyers manifested a strike action in which their grievance or cause of strike was mainly because of the imposition of Civil Law tradition in the Common Law courts in the two Anglophone regions. In addition, Cameroon became an official member of the Organization for the Harmonization of Business Law in Africa (OHADA). The major language of OHADA is French. The Anglophones were dissatisfied because OHADA's judicial acts were devoid of English language, making it difficult or impossible for Anglophone lawyers to understand and practice in law courts (Fonkoué, 2019). 


\subsection{Relevance/Rationale of Study}

It should be recalled that after Cameroon's reunification in 1961, the country was known for its relative peace and serenity. An important ramification of post colonialism for Cameroon and other former colonies is development or nation building. As a result, Cameroon's efforts towards nation building and/or development after its independence ought to have prompted the head of state to reflect on its journey of unity and its dual heritage and to take into consideration whether or not the country has a "sense of [a] collective journey" and "a movement driven by the sentiment of a common destiny" (Homi Bhabha, 1990, as cited by Fonkoué , 2019, p. 8). Instead, the president neglected the country's dual heritage. Fonkoué (2019) draws from Foucault to expand on the notion of colonialism:

[D]iscourse produces dominant knowledge through language and action. For Foucault, what is at stake in discourse is the power dynamics. Discourse is the prerogative of those who are in a position to speak, to decide who speaks, or to validate what is said. From this perspective, discourse invites action, and naturally translates into action. [Also] Foucault considers discourse, as a social practice, to be the terrain where power dynamics are at play. (p. 9).

As such, rhetorical analysis offers a lens to pay critical attention to the underlying discourses in this crisis. Analyzing the discourse on the ongoing crisis is important because as a rhetorical critic, I am able to uncover the narratives and make determinations of the motive of the rhetors whose discourse I am analyzing. Uncovering the narratives and making determinations on the motives of the actors in this crisis, is a 
huge contribution towards future recommendations in resolving this crisis. This thesis sets out to contribute to this end. To attain this goal, this colonial and postcolonial history and discourse mentioned in this section is vital as it provides a strong context for the analysis that I conduct.

Moreover, the nonexistence of a homogenous law being practiced in the Francophone and Anglophone regions as a residual of colonialism is a call for concern because instead of uniting the country as a whole it has led to disparity. This action further solidified the reason for the outbreak of the Anglophone crisis, which is ongoing.

Since the outbreak of the crisis, about 3000 people have been killed and over 500,000 displaced into neighboring countries including Nigeria (Kindzeka, 2019). People live in fear and kidnappings have increased as guerilla fighters now target individuals for ransom. The economy of the Anglophone regions, hence, that of the country, is hard-hit. Clearly, I see this study as an opportunity for me to explore the narratives through which the crisis has been framed and examine the implications of these narratives for the ongoing war. This is important as the country searches for a way out of the war, and to propose some recommendations towards the resolution of the crisis. The Anglophone activists are the main perpetrators of the war as they aim to secede completely away from French speaking Cameroon. It should be noted that the president is from the French speaking part of Cameroon. As such, with the intervention of armed forces of the country, he strives to stop the war. 


\subsection{Scope of Study}

This study covers artifacts published on Facebook on and about the Anglophone crisis between September 10 and December 31, 2019. This is the time period during which there were many postings and reactions from both the president of the republic and activists. This was primarily because the president of the republic had called for a national forum to address the Anglophone crisis. The forum (the National Dialogue) was scheduled to run from September 30 to October 4, 2019. The president of the Republic also addressed the nation on December 31. This further ignited postings on and about the Anglophone crisis from activists and published this speech on his Facebook page. The artifacts for this study are Facebook posts by the president of the republic and one prominent Anglophone Cameroonian activist by name Mark Bareta. I choose Bareta because he has emerged as a mouthpiece of the secessionist movement among several others whose pages I follow. Bareta has been endorsed by pro-independence Anglophone activists, as seen in the "shares" that his posts get from other activists. Bareta had over 150,000 Facebook followers (one of the highest of any individual pro-secessionist Anglophone activist at the time artifacts for this study were collected).

The president's Facebook page has a wide range of content - from official communication in connection to the Anglophone crisis, reforms, policies, meetings with foreign diplomats, official appointments (nominations) of individuals into government positions, presidential state visits to other countries to congratulatory messages to other nations (especially those celebrating national days) and condolences to nations struck by disaster. The President of Cameroon has close to one million followers. Mark Bareta, the 
prominent activist whose page I am also analyzing, mostly publishes posts on the Anglophone crisis. Some of these posts are created by the activist, while some are those he shares from other sources.

Since I am analyzing an activist's posts, it is important to discuss some understandings of activism as used in my research. According to Brian Martin (2007), activism is defined as an "action on behalf of a cause, action that goes beyond what is conventional or routine" (p. 1). Activism depends on the cause and at most times, individuals who take part in activism were influenced by some other person. The term activism is neither a negative nor a positive term, but its connotation is dependent on the context in which it is applied. Also, Martin (2007) describes activists as "members of groups, which can be small or large, local or global" and such groups can be radical in their activities, peaceful or simply rallying for change (p. 1). In this study, Mark Bareta, the activist falls within these categories - rallying for change (secession), he could be seen as a radical or peaceful, depending on which side of the aisle one stands.

In chapter 2, I present a literature review of several works that use cluster analysis as method of rhetorical criticism. In doing so, I point to gaps which those studies failed to address, and I discuss how my work addresses the gaps, thereby contributing to rhetorical theory. I also provide a conceptual discussion of cluster analysis as method as well as the rhetorical criticism as a larger framework for this study. The artifacts and sources of the artifacts will also be described in chapter 2 . 


\section{Literature Review}

\subsection{Introduction}

This chapter provides a brief overview of scholarship that has applied the method of analysis that I use in this study - cluster analysis. In doing so, I aim to point to the strengths of using this method of rhetorical criticism and discuss gaps in scholarship on the works that I review. Given that cluster analysis is only one of several different methods of rhetorical criticism, this chapter will include discussions on rhetorical criticism as the broader framework for my work. The goal is to provide a rationale for both my research method and theoretical framework as applied in this research work. The artifacts for this study will also be described in this chapter to provide the methodological context for the next chapter which focuses on data collection and other aspects of the research method design. The research questions for this study are also stated and discussed in this chapter. The following section offers a review of literature tracing the foundation and conceptual perspectives of cluster analysis as a method in the broader rhetorical criticism framework, its application and discussion of the gap in scholarly works relating to the application of the method, and then, briefly explains how this study fills the gap.

\subsection{Brief Overview of Scholarship on Cluster Analysis}

Before discussing and reviewing scholarship that has applied cluster analysis as a method of rhetorical criticism, it is important to first discuss the views of the founder, Kenneth Burke, on rhetoric because it is within the purview of Burke's conceptualization of rhetoric that we get a strong perspective on cluster analysis. Burke's academic work 
cuts across several disciplines. Burke (1950), defines rhetoric as "the use of language to form attitudes and influence action" (p. 18). In addition, the author draws from Cicero's dialogue De Oratore to define rhetoric as "Speech designed to persuade" (Burke, 1950, p.49) and from Isocrates "the craftsman of persuasion" (p.49). Burke further asserts that, "rhetoric seeks rather to have a formative effect upon attitude" (p.50). The author alludes to Quintilian's perspective of rhetoric “as a power, art or science that identifies right doing with right speaking" (p.51). To further add to the definition of rhetoric, Burke (1950) mentions that

rhetoric is not rooted in any past condition of human society. It is rooted in an essential function of language itself, a function that is wholly realistic, and is continually born anew; the use of language as a symbolic means of inducing cooperation in beings that by nature respond to symbols (p.43).

These definitions of rhetoric drawn by Burke in his work substantiate his overarching idea of how language is used by an author and/or rhetor for a purpose including the purview of rhetorical analysis. Also, key to Burke's definition of rhetoric is the focus on cooperation, and identification over persuasion and agonistic rhetoric. To have a deeper understanding of what rhetorical criticism is, it is essential to have a comprehensive definition of rhetoric from the perspective of other scholars. The canonical figure associated with the study of rhetoric is Aristotle, amongst others. Drawing from Aristotle's early scholarly works, Zerba (1990) mentions the definition of rhetoric "as the available means of persuasion" (p.244). In the same line of thoughts, Foss (2018) 
explicates rhetoric as "the human use of symbols to communicate" (p.3). Foss further elaborates on the definition of rhetoric by providing three fragments of the meaning of rhetoric. That is, "humans as the creators of rhetoric, symbols as the medium for rhetoric and communication as the purpose of rhetoric" (p.3). Foss (2018), portrays humans as originators of rhetoric because humans create symbols to represent a particular connotation. In addition, Foss (2018), asserts that rhetoric is a "medium" or vehicle through which discourse is produced. According to the author, "symbols" are intended for communication with others or oneself" (p.5).

I will be referring to Burke's literary works such as Rhetoric of Motives (1950), Grammar of Motives (1945), Language as Symbolic Action (1966) and The Philosophy of Literary Form (1941) to provide insight on and about cluster analysis.

According to Burke, in as much as persuasion is primordial to understand the meaning of rhetoric, identification is as well important. However, Burke (1950) asserts that the major concept for rhetoric "is not identification but persuasion" (p.xiv). This is because the focus of rhetoric for a long time has been persuasion. Burke is arguing that persuasion has historically been the main focus of rhetoric; he is broadening and refocusing that definition to include identification. As a result, identification is also essential in rhetoric as persuasion because it aggregates members of a group who share similar goals (Burke, 1950). Additionally, identification can be deciphered as the ability of a rhetor to relate to an audience through a common trait or "interest" (Burke, 1950, p.xiv). To add to the meaning of identification, (Jay, 1985; Bizzell and Herzberg, 1990) note that "identification means to suggest more than persuasion the workings of rhetorical 
discourse in everyday language" (p.1296). As a result, an individual can only identify with another insofar as they have a common interest and not because they come from a similar geographical location or similar profession.

Burke (1950), mentions the similarity between "identification" and "persuasion". According to Burke, a "speaker" or rhetor can successfully "persuade an audience with the help of "stylistic identifications" (p.46). Moreover, the rhetor's "act of persuasion may be for the purpose of causing the audience to identify itself with the speaker's interests" (p.46). Burke asserts that "the speaker draws on identification of interests to establish rapport between himself and his audience" (Burke, 1950, p.46). As a result, a rhetor can effectually influence a target audience in so far as they have a common objective. This creates a favorable opportunity for an audience to perceive a rhetor's speech as trustworthy. Burke (1950) uses the term "consubstantiality" as close in meaning to "identification". Nonetheless, the two terms are different in that, to be consubstantial, one must "have common sensations, concepts, images, ideas, attitudes that make them consubstantial" (p.21). That is, the two terms, "consubstantiality" and "identification" are different in that, for a rhetor to identify with an audience, they both need to first have a common interest. On the other hand, for individuals to be consubstantial they do not necessarily have a common approach towards achieving a goal. Burke (1950) notes that an individual can easily persuade another person "by identifying your cause with his interests" (p.24). In the case of this study, activists identify with each other because they share a common interest to secede away from French speaking Cameroon as mentioned in chapter one. However, the activists are not 
"consubstantial" because whilst some activists take a radical approach in their riots, others maintain peace and serenity in the country while advocating peaceably. In Burke's Rhetoric of Motives, he mentions that "Identification is affirmed with earnestness precisely because there is division" (p.22). This explicates why separatists in Cameroon have different approaches in achieving their main aim to break away from French speaking Cameroon.

To further understand the importance of identification and consubstantiality, it is invaluable to have a grasp of how useful language is to rhetoric. In Burke's Language as Symbolic Action, he defines language as a "symbolic action" (p.45). Burke (1966) portrays man as a "symbol-using animal" (p.3). According to Burke, the words that come out of a man's mouth originate from "our animality" and our "symbolicity" (Burke, 1966, p.6). He elucidates more on this with a Biblical figure, Paul who asserts that "Faith comes from hearing." This is the reason why people get "brainwashed" as a result of what they have been listening to continually by an author and/or rhetorician (p.6). In the case of this study, Anglophone activists were easily influenced to riot by the originators of the strike action that is, the Anglophone lawyers and teachers because of their continual call for action by the Anglophones. To elaborate more on the "nature of language" (p.44), Burke provides the difference between "scientistic" and "dramatistic" representations of language. According to Burke (1966), "a scientistic" approach begins with questions of naming, or definition...or viewed as derivative; [it] may be treated as attitudinal or hortatory" (p.45). On the other hand, he defines the term dramatism as "[a] technique of analysis of language and thought as basically modes of action rather than as means of 
conveying information” (Burke, 1966, p.54). Burke further explicates the usefulness of language stating that

$[\mathrm{t}]$ he instrumental value of language certainly accounts for much of its development... and may even have been responsible for the survival of language itself...in developing atomic power now threatens the survival of the language-using animal...Language is a species of action, symbolic action-and its nature is such that can be used as a tool. (p.15).

Drawing from Burke's assertion of language as "scientistic" and "dramatistic," a rhetor can use language to define and/or rename a cause to favor their purpose. As such, Burke's portrayal of language as a "symbolic action" points at how verbal and nonverbal communication is a strong representation of the powerful utility and importance of language and build on each other.

Additionally, Burke (1966) portrays man as the "inventor of the negative" (p.9). According to Burke, "there are no negatives in nature" (p.9) however, because man is the creator of "human symbol systems" (p.9) language can be used for dubious purposes without acknowledging its negative consequences. Burke refers to this as "the principle of negativity" (p.12). To elucidate more on how language can influence an audience, Burke (1950), notes that "imagery" is important because it helps in "characterizing a given motivational recipe" in addition to "its rhetorical effect upon an audience" (p.17). As a result, an author can easily use language to manipulate an audience. Moreover, Burke notes that an audience can grasp the worldview of a rhetor through the terminology 
they use, including imagery and negativity. He refers to this ability to discern meaning as an application of "terministic screens" (p.45). This concept will be further explicated in the next section. Drawing from the artifacts for this study, that is, Facebook posts from president Biya's page and Mark Bareta's page, the rhetorical critic can deduce the key terms used by both rhetors because of the intensity and frequency. As a result, the critic can penetrate the worldview of both rhetors.

Taking into account that we have some insights on Burke's views on rhetoric to be how language can be used as a tool, persuade an audience and impact action, the next section discusses cluster analysis and provides an overview of some works that have used the method, then discusses the gaps in the use of the method.

To have a better understanding of what cluster analysis is, it is invaluable to recall the meaning of identification, consubstantiality and persuasion as defined by Burke and mentioned earlier. It is important to note that cluster analysis works in tandem with Burke's pentadic analysis or criticism. I will first briefly explicate cluster analysis. A rhetor can successfully use rhetoric to persuade an audience towards a goal in so far as they identify with their audience. As such, rhetoric through the rhetor's ability to identify with their audience "represents a creative strategy for dealing with that situation" (Foss, 2018, p.62). With the use of an artifact, a rhetor shares his worldview through a consistent use of vocabulary, emotions and actions. As a result, the rhetor makes use of particular terminology which Burke refers to as "terministic screens" in order to accentuate the intensity of particular ideas. However, even though "terministic screens" could be used intentionally, they are not always applied consciously by a rhetor. This is 
because, an audience can uncover the motives of a rhetor by analyzing elements of human relations which Burke refers to as pentad (Burke, 1945). Burke outlines the elements of the pentad as: act, agent, agency, scene and purpose (Burke, 1945). According to Burke (1945), elements of pentad denote a means of examining a rhetor's behavior and action. In Burke's Language as Symbolic Action, he mentions that terministic screens "direct the attention" (p.45) of an author or rhetor and is also "terminology [which] is a reflection of reality" (p.45). This helps the audience to provide a narrative towards a rhetorical situation.

To conduct a cluster analysis, it is important to first understand the representation of each term and/or symbol for a rhetor. As such, "terministic screens" offer a critic the opportunity to critically reflect on "how terminologies come together into clusters so that they reflect and reproduce particular understandings of reality" (Angel \& Bates, 2014, para. 5). A paramount aspect of cluster analysis is the fact that the significant key terms for a rhetor are identified by charting the terms that cluster around the key terms. By charting these terms, one can discover which narratives or ideas match which. Burke (1966) provides insight to how words can be used by a rhetor. According to him, words can be "a link between us and the nonverbal" and also "a screen separating us from the nonverbal" (p.5).

Furthermore, in Language as Symbolic Action, Burke elucidates on the saliency of the rhetor's use of terminology. A rhetor frequently uses particular term(s) to illustrate the extremity of rhetorical situation such that the audience can grasp that in their worldview. Burke provides an example to facilitate an understanding of terministic 
screen. According to Burke (1966), "If you want to operate, like a theologian, with a terminology [such as] "God" as its key term, the only way to do so is to put in the term, and that's that" (p.46). This is significant because for a rhetor to convey a particular ideology across an audience, they have to include a particular terminology in their speech. In the case of this study, the activists whose Facebook pages I am analyzing, that is president Biya and Mark Bareta, use a particular terminology in their posts in order to emphasize some main purposes. For example, the president refers to the "Anglophone problem" as "crisis" which denotes a negative circumstance and encourages peace. On the other hand, Mark Bareta refers to the "Anglophone problem" as a "revolution" to portray it as a positive incident and to galvanize more activists towards achieving autonomy.

In the following paragraphs, I discuss the scholarly works of some authors who have applied cluster analysis as a research method in rhetorical criticism. The purpose is to draw attention to the type of artifacts that other scholars have used and the commonalities that exist in how these scholars approached their analysis. I will categorize these articles and also provide the limitations that some of the authors pointed out when applying cluster analysis in their research.

Foss' (2018) work on rhetorical criticism is very influential in this study. In addition to the description of cluster analysis and other helpful insights to the field of rhetoric, Foss has also applied Burkean cluster analysis to analyze the differential narratives from the media and the role of crisis leadership concerning Hurricane Katrina that occurred in 2005 in Louisiana. Burke (1950) notes that, "persuasion implies an 
audience" (p.38). As such, for the media to provide a dominant narrative concerning the hurricane an intended audience was required. Foss (2018) mentions that in order to apply this rhetorical method successfully, it is primordial to analyze the terminology used frequently by different media organs in reporting the hurricane. Burke refers to this as "terministic screen" to assess the rhetor's worldview. Foss (2018) asserts that she analyzed fifty-two articles published in two newspapers, namely, The New York Times and the Times-Picayune of New Orleans. According to the author, she chose print because "it provides a more holistic picture" (p.75). The author noted that at the early stage of the hurricane, the clustering terms surrounding authority figures were positive, but as the life-threatening incident continued the clustering terms became negative. As a recommendation, Foss (2018) states that,

Authorities in crisis situations also need to acknowledge the privileged position of media and monitor closely the terms they use to characterize responses to a crisis. Because language influences perception. Also, future studies should explore the responses of authorities during different stages of crisis. Additional investigation of crisis through the rhetorical lens may yield a more sophisticated level of understanding when explaining the language used by the media when reporting on a crisis (pp.85-86).

Foss (2018) draws our attention to how an audience can be easily influenced by a rhetor's speech and consequently overlook the purpose of their motive. Burke (1950), asserts that "by showing how a rhetorical motive is often present where it is not usually 
recognized, or thought to belong" (p.xiii). This is applicable to how the media might report an event portraying a particular angle meanwhile there is a state of urgency which the audience ignores. As a result, "rhetorical elements that had become obscured [become] rediscover[ed]" (Burke, 1950, p.xiii).

Berthold, (1976) is a rhetorical critic who also used cluster analysis in a study. The critic analyzed John F. Kennedy's message, To Turn the Tide and one of his public statements from his election in 1961. In addition to cluster analysis, Berthold (1976) applied a "cluster-agon" analysis method in her study. According to her, the rationale was for the purpose of "objectivity" because cluster-agon analysis helps a critic to "gain an objective picture of the rhetoric of a given speaker" (p.309). The critic notes that, clusteragon analysis "provides a way of comparing the rhetoric of several speakers [and] could be used to describe similarities and differences between opposing candidates' positions in a political campaign" (p.309). In the same line of thought, Burke (1945) mentions the significance of a rhetor's use of terms or gestures as he asserts that, "an act or any verb no matter how specific or general...has connotations of consciousness or purpose" (p.140). Berthold (1976) also notes that, cluster analysis can be applied to examine how a rhetor's key concepts are understood by his audience. In the case of Berthold's analysis of John F. Kennedy, it was important to grasp the worldview of the author by examining his key terms in opposition, the god and devil terms. This terminology will be further described in the following chapter. However, the critic recommends that cluster-agon analysis should provide a useful and usable tool which rhetorical critics can gain new perspective" (p. 309). 
An interesting perspective on cluster analysis emerged with Walton's (2013) article in which he analyzed President Obama's argument for higher education reform. Walton did not use god terms and devil terms in his analysis. Rather, the analysis focused on "similarly categorized themes" informed by terms and phrases (p. 40). The following themes emerged, or clusters emerged: defending/championing the middle class; the cost of higher education; and the value of higher education. Walton was able to make a determination on the Obama's worldview as suggested by the thematic clusters. Walton's analysis shows that a rhetorical critic can conduct a cluster analysis with or without the use of god terms and devil terms, and rather opt for underlying themes informed by key terms.

On the other hand, Dunn et al. (2017) applied cluster analysis in the nursing field. The authors note that they applied cluster analysis to their research because of its relevance and suitability in several fields of study. Drawing from Aldenderfer and Blashfield, (1984), the authors point out four main applicability of cluster analysis: to “create classifications of homogenous groups; discover new relationships or investigation of conceptual schemes; hypothesis testing and confirmatory analysis of previously identified classifications (p.1661). In addition, the authors mention that the exclusive choice to apply cluster analysis is contingent on factors such as the researcher's goal, questions, data collection and others. Dunn et al. (2017) point out that cluster analysis is mostly applied in the nursing field in order to "focus on homogenous groupings of patients, nurses, caregivers and nursing students" (p.1672). Nonetheless, the authors mention that a limitation of using this method in the nursing field is the fact that "the use 
of nursing literature is limited to the creation of classifications of homogenous groups and the discovery of new relationships" (p.1672). In addition, Dunn et al. (2017) note that a vigorous cluster analysis can create plausible research findings that will eventually ameliorate the health of patients.

Additionally, Dolnicar (2002), applied cluster analysis as a research method to review unquestioned standards for data-driven market. The author assessed 243 datadriven scholarly articles about business administration. According to the author, cluster analysis is mostly applied "in a non-explorative manner" and "lack of match with data conditions" (para. 1). In order to do an accurate analysis, the author applied several forms of clustering algorithms. However, the author asserts that the outcome of the findings is contingent on the selection of clusters. Dolincar (2002) mentions that in order to approve the results of the analysis, it is imperative to repeat the research procedure several times with various clusters and algorithms.

Newby and Tucker (2004) applied cluster analysis as a research method to empirically analyze eating patterns. Based on the authors' findings, eating patterns are not contingent on several authors' explications of a healthy pattern. According to the authors, cluster analysis is an efficient method of classifying data and/or grouping categories of variables into clusters because "they are mutually exclusive and continuous" (p.197).

Angel and Bates (2014) did a study that explored understandings of corruption in Colombia. They analyzed a public talk on Hora 20 (a popular Colombian radio program). 
Angel and Bates used Burke's concept of terministic screens together with Burke's method of cluster analysis. The authors found that "Hora 20's radio speakers express six terministic screens regarding corruption" (para. 1). The clusters that emerged from their study according to the authors, "triggers different programs of action with diverse linguistic and practical implications... for addressing problems of corruption in Colombia" (para. 1)

These works provide great insights on the application of cluster analysis as a method of rhetorical criticism. My observation from these studies is that the method was not applied in a political crisis of a complex nature like the ongoing Anglophone Crisis in Cameroon. Another observation was that these articles did not analyze social media posts. This is my contribution to rhetorical theory. It is thus, significant to see how "nonwestern" political actors' narratives are examined through the lens of cluster analysis which, according to the brief review of literature for this study, shows have been largely applied in western rhetorical contexts. This gap, which my study hopes to fill, is important because it would not only increase knowledge on the applicability of cluster analysis in narratives occurring in predominantly "non-western" contexts, but also advance understandings of the method's application in complex "non-western" political and historical contexts that rally the political elites as well as activists - both actors who advance narratives with strong differences in the civil discourse.

In the meantime, since cluster analysis is a method of a broader framework of rhetorical criticism, the next section discusses rhetorical criticism as the overarching conceptual framework for my research. This discussion will help provide additional 
insights that enhances understanding of both my method of analysis and the lager conceptual framework.

\subsubsection{Conceptual Framework}

According to Foss (2018), rhetorical criticism "is a qualitative research method" intended for a "systematic investigation and explanation of symbolic acts and artifacts for the purpose of understanding rhetorical processes" (p.6). It is also a research method used to better understand language as a symbol of communication and intended to get a designated feedback from an audience. Our knowledge and reasoning towards a particular idea are created from symbols. As a result, rhetorical criticism can be explained as a process in which people get involved in trying to understand symbols and know how they influence our behavioral pattern. This is experienced in our daily activities such as engaging in conversations with others, reading and watching videos for a particular purpose (Foss, 2018).

In addition to Burke's cluster analysis, agon analysis is another rhetorical criticism method which works in tandem to cluster analysis. Berthold (1976) notes that, cluster analysis is not "complete" as a lone method of analysis because "it lacks a sense of conflict and drama [these qualities are accentuated] in an agon analysis" (p.303). Burke (1945), mentions the importance of drama as "the basic unit of action [and] "the human body in conscious or purposive motion" (p.14). According to Berthold (1976), an agon analysis is important because it "reveals those terms which are in opposition to each other" (p.303). The agon analysis works similarly to the cluster analysis. With both methods of analysis, a rhetorical critic must identify key terms in the rhetor's 
terminology, that is, the "god" terms and "devil" terms, in addition to other concepts used by the rhetor so as to examine the rhetorical situation in which they are applied. This will help in "determining the terms which it opposes...in a form of contraposition" (p.304). Berthold (1976) further asserts that,

Agons may involve direct opposition between terms, as when the speaker contrasts a good and a devil term. Opposition may also be expressed by describing a form of competition between two terms...Agons like clusters, may be formed indirectly by opposing each other through mutual relationship to third terms (p.304).

Furthermore, it is important to note that the intensity and frequency in which opposing terms of a key term contrast each other highlights its saliency in the rhetor's worldview. Berthold (1976) draws from Rueckert (1963), to mention that "the opposed principles represent the self's choices, and the movement towards and away from them... represents the quest, the self's journey toward unity of being” (p.304). Having described the conceptual approach to cluster analysis method and rhetorical criticism as a larger framework for this study, I will now turn to a discussion on the artifacts and their sources for the cluster analysis that I conduct in chapter 3.

\subsection{Artifacts for Analysis}

For this study, I will be analyzing text (posts) published on Facebook on and about the Anglophone crisis between September 10 to December 31, 2019. This is the time period in which there were many postings and reactions from both the president of the 
republic and activists. This was primarily because the president of the republic had called for a national forum to address the Anglophone crisis. The forum was scheduled to run from September 30 to October 4, 2019.

Clearly, the artifacts for this study are Facebook posts by the president of the Republic of Cameroon, Paul Biya, and one prominent Anglophone Cameroonian activist by name Mark Bareta. The next section discusses the research questions for this study.

\subsection{Research Questions}

This study will address the following research questions which are helpful to uncover the worldview of President Biya's rhetoric towards the Anglophone problem and the role of Anglophone activists towards the proliferation of the strike action into a civil war.

1. What are the descriptive narratives that emerge from the actors?

2. What do these narratives tell us about the actors' motives?

Research Question 1 focuses on the narratives put forth by the two rhetors in this study. Investigating the narratives that emerge from these actors clustering the narratives around particular categories is important because through those narrative clusters, we can determine the worldviews held by these two actors and thereby not only discern their motives, but also identify potential points of identification and consubstantiality. It is important to note that these two actors belong to two heavily disparate social classes. The president of the republic is not only of the elite class in the country, but also, the decision-maker, with powers to influence the decisions of other members of the elite 
class, and even determine the direction of the crisis. Mark Bareta essentially represents the "underdogs" whose views have influenced the current state of the crisis - from street protests that turned into deadly riots, to a full-blown war between separatist fighters and government forces in the Anglophone regions of the country. Clustering their narratives into categories could help us to make determinations of their motives. To achieve this understanding of the rhetors' motives, I intend to cluster each individual's narratives first, and then look at the clusters together. According to Burke, (1941), "Ingredients composing a cluster...could be treated as representing the rest" (p.27). As such, this is clearly to portray the intensity and frequency of each individual's cluster to have a better understanding of whether or not they represent a "god" term or "devil" term as a tool towards their motives. I will further look at the significance of these terms with regards to cluster analysis in the following chapter.

Understanding the motives of these two political actors is important because they essentially represent two dominant classes of rhetors in the ongoing crisis - President Biya would represent the dominant class, while Mark Bareta represents the subjugated classes. Understanding their worldviews and making determinations of their motives would further help this research to put forth recommendations that, if taken into account by decision makers (e.g., national actors, and world partners, including international organizations) seeking to mediate in the ongoing crisis, could contribute to seeking lasting solutions to the crisis. This is a major rationale for this study.

Research Question 2, as already mentioned, sets out to make determinations of the motives of the rhetors whose narratives are analyzed in this study. I also discussed the 
rationale of examining the motives of the rhetors. Overall, these two research questions can adequately be investigated using Burke's cluster analysis. The artifacts in the study written texts - are among the most feasible artifacts for a rhetorical criticism framework that uses cluster analysis as method (Foss, 2018).

In the next chapter, I focus on the data collection process, a more detailed description of the artifacts, and delve in greater details of cluster analysis' application in this study. 


\section{Methodology}

\subsection{Introduction}

In chapter 2, I provided a conceptual overview of the method (cluster analysis); discussed some scholarship that applied the method; stated what I considered to be the gap in those studies; mentioned how my work fills the gap. I also discussed the larger framework of rhetorical criticism within which cluster analysis is one of many methods. The discussions on cluster analysis as well as the larger framework of rhetorical criticism in chapter 2 is grounded primarily on Burke's conceptualization of what constitutes clusters and how clusters function; the role of rhetoric and how we should understand rhetoric. An understanding of Burke's perspectives on rhetoric is necessary if we are to fully grasp the scholar's cluster analysis method. In chapter 2, I also briefly described the artifacts that will be analyzed in this thesis as well as the research questions that guide my thesis. In this chapter, I focus on the practical steps that a researcher must follow when using cluster analysis as method of rhetorical criticism. For better comprehension, while I rely on Burke to discuss these steps (since cluster analysis is his method), I also draw on the work of Foss (2018) and Berthold (1976). Clearly, Burke doesn't really discuss cluster analysis as a method; therefore, it is essential to draw on the work of scholars like Foss and Berthold who have operationalized it.

Also, this chapter describes the data and data collection process, mentions what was not counted as data, discusses the procedure for categorizing (coding) data, and details the process for the analysis that provide answers to the research questions 
discussed in chapter 2. I should point out from the outset that data collection and analysis detailed in this chapter are aimed to answer the research questions discussed in chapter 2:

RQ 1: What are the descriptive narratives that emerge from the actors?

RQ 2: What do these narratives tell us about their motives?

What follows is a step by step description and discussion of cluster analysis as method for my study.

\subsection{Method - Cluster Analysis}

According to Berthold (1976), "Burke's method offers an objective way of determining relationships between a speaker's main concerns [in addition to] a new perspective to rhetorical critics who desire to discover more about the motives and characters of speakers" (p.302). Even though cluster analysis originates from Burke, Berthold (1976) remarks that the author did not explicitly provide a step by step procedure on how to apply the method in rhetorical criticism. Foss (2018) draws from the conceptual lens provided by Burke to enhance understanding of the procedure for researchers applying the method. I follow the steps discussed by Foss in conjunction with perspectives from other scholars (e.g., Berthold) who draw from Burke's original prescription to determine the procedure for cluster analysis. The following are steps to follow when conducting cluster analysis. 


\subsubsection{Procedure}

The first step for conducting a cluster analysis is for the researcher to select an artifact. Foss (2018) suggests that when selecting an artifact, a rhetorical critic should choose an artifact that is "complex enough to contain several terms that cluster around the key terms in the artifact” (p. 64). Written texts and/or speeches work best with cluster analysis compared to using images or other non-textual artifacts (Foss, 2018). Selecting an appropriate artifact is followed by the second step in which the rhetorical critic identifies the salient terms from the rhetor's and/or author's speech or text (artifact). According to Burke, drawing from the rhetor's speech or text, a rhetorical critic can make inference to a "god" term versus a "devil" term". Clearly, Burke (1966) asserts that such terms should be referred to as terministic screens and called particularly "god" terms and “devil” terms. In his work The Philosophy of Literary Form (1941), Burke notes that "any verbal act [should] be considered as symbolic action" (p.8). Berthold (1976) draws from Weaver's and Regnery's The Ethics of Rhetoric (1953) to describe the "god" term to be "that expression about which all other expressions are ranked as subordinate and serving dominations and powers" (p. 303). Weaver (1953) also refers to the "god" terms as "good terms." According to Berthold (1976), the "god" terms are decisive because they "appear to receive a society's greatest sanction [and] the very highest respect is paid" (p.303). Moreover, Berthold (1976) defines a "devil" term to be "the counterpart of the god term" (p.303). Foss (2018) points out that the key terms must be "nounssubstance words" (p.64) such that they can "reference people, places, objects or ideas" (p.64). 
The terms frequently used by the rhetor depict the intensity of the rhetorical situation being referred to by the rhetor. Clearly, the terms should be identified "on the basis of frequency or intensity" as well as how the author uses the terms "over and over" (Foss, 2018, p.64). Thus, after the key terms of the rhetor's and/or author's speech or text are identified, a rhetorical critic can focus on how intensely and how frequently each key term was applied in different contexts. Berthold (1976) notes that the extent to which each key term is applied is a function of "the comparative intensity and frequency of its use; the strength and clarity of its imagery; and the frequency with which it is linked with other key terms" (p.303). When focusing on the intensity and frequency of the key terms, the rhetorical critic charts the terms of the artifact "that cluster around those key terms" (Foss, 2018, p.65). To understand the representation of each term as a cluster, Burke (1941) mentions that the cluster should be chosen on the basis of "what goes with what" (p. 22). Following the charting process, the rhetorical critic should provide an explanation of trends or clusters discovered during the process of "charting [and] clustering" of the terms found in the artifact in order to reveal or discover the rhetor's "worldview" (Foss, 2018, p. 66).

After charting and clustering terms and providing an explanation of what was discovered during the clustering process the rhetorical critic addresses the research questions for the study (Foss, 2018). In doing so, the rhetorical critic should be attentive to the trends that stemmed from grasping the representation of the key terms used by the rhetor. The concluding steps, which I report in the final chapters of my thesis, include outlining results or, findings, discussing possible interpretations of the results, discussing 
the implications and/or recommendations of the research, and posting its contribution to rhetorical theory. The next section discusses the data and collection procedure in this study.

\subsection{Data for the Study}

As mentioned earlier in chapters 1 and 2, the artifacts for this study are written posts from the Cameroon president's Facebook page as well as posts published by a prominent Anglophone activist, Mark Bareta, on his Facebook page. I chose the president's Facebook's because he is the head of state and the ultimate decision maker in Cameroon, and he was heavily implicated communicatively in the crisis. As a primary rhetor in the crisis, he used Facebook posts to communicate directly to the public, sharing excerpts of the state of the nation's address on his Facebook page. I chose to analyze Mark Bareta's Facebook page because of his prominence as a civil society activist on Facebook and he has many followers as well (about 150, 0000). He published posts on and about the Anglophone crisis, while other Anglophone activists tag him to their Facebook posts concerning the Anglophone crisis.

When collecting the data, I did a screenshot of Facebook posts on the president's and Mark Bareta's Facebook pages. These posts were screenshot for the period of September 10 to December 31, 2019 (cf. chapters 1 and 2). The screenshots were saved in a file on my desktop. I later looked through the posts and selected five posts published by president Biya and one post published by the activist, Bareta. The decision to select five posts from Biya's Facebook page was informed by the fact that Biya's posts were 
brief, so selecting more than one post will enhance my ability to make sense of the narratives which Biya was putting forth. On the other hand, Bareta's single post was the length of a short speech with enough text for analysis. As such, I did not deem it necessary to select more than one post from the activist's Facebook page. So, in total, six posts were selected for analysis.

\subsubsection{Description of Artifact 1: President Paul Biya's Facebook Posts}

While cluster analysis works with both discursive and non-discursive artifacts, discursive artifacts have dominated cluster analysis conducted by rhetorical critics (c.f. Foss, 2018; Berthold, 1976; Angel and Bates, 2014). As mentioned earlier in the previous section, I did a screenshot of posts published on president Biya's Facebook page within the time frame running from September 10 to December 31, 2019. These posts were messages he communicated to the public and fall in the category of discursive artifacts. As already described in chapter 1, the president's Facebook page consists of decrees signed by the president, appointments of individuals into government positions by the president, the president's congratulatory messages to other heads states celebrating their country's national day, condolence messages to government officials including foreign counterparts, and information about political happenings in the country. I decided to screenshot only posts pertaining to this study, that is, posts on and about the ongoing Anglophone crisis. I did screenshots of fifteen posts on the president's Facebook page. These posts consisted of the president's reaction towards the crisis, his feedback and stance about the Major National Dialogue which he convened for September 30-October

4, 2019 in order to address and mitigate the Anglophone crisis (even though the president 
was not in attendance, the National Dialogue could not have been held without him decreeing that it should be held). As mentioned in chapter one and earlier in this chapter, the president decided to convene a National Dialogue to seek solutions to the Anglophone problem and address other important issues of concerns in the country.

The posts on president Biya's page are very brief in content. Some posts are only eleven words long; the longest post is ninety-four words. I initially chose two posts from the fifteen that I had screenshot; but the two posts were not detailed enough and I was not able to be fully immersed in Biya's discourse only by looking at those two posts (the result of the brevity of the posts). To have a strong understanding of the key terms used and be able to determine terms that clustered with key terms, I decided to select a total of five of president Biya's posts. The five posts selected were those with the highest reactions and comments from the public. The comments and reactions to these posts came from those sympathetic to the president's handling of the crisis, as well as from those critical of the president's handling of the crisis. The five posts were also among the longest found on the president's page, ranging between twenty and ninety-four words. These posts were published between September 10 and October 4, 2019. It is important to note that the period during which these posts were published marks an important turning point in the president's public statements on social media considering that the president previously had been particularly mute on the crisis. The president would only make public statements on and about the crisis during a televised end of year address to the nation for the past years following the outbreak of the crisis since the start of the crisis in 
2016. These rare addresses did not provide opportunities for a wider public reaction in real time compared to social media platforms.

Clearly, therefore, the posts I am analyzing from the president's Facebook page received strong reactions from Anglophone activists in Cameroon and those living in the diaspora. However, even though the Anglophone activists living in the North-West and South-West regions are those mostly affected by the crisis, some Francophones reacted to the president's posts as well. This is because they feel affected by the lack of serenity and peaceful atmosphere that once existed before the outbreak of the crisis in the country. In addition to the comments on the president's posts, users also used emojis as an expression of their emotion and a communication tool strategy as well. The posts I chose to analyze on the president's page mostly had a "thumbs up," "a heart emoji" and a "laughing emoji." After I read through some of the comments of those who reacted towards the president's posts, I deduced that those who used a "thumbs up" represented joy and high expectancy from the president to mitigate the crisis. Those who used a heart emoji represented those who wrote comments expressing feelings of patriotism towards the country. Similarly, those who used a laughing emoji represented those who made mockery of the president's action towards unifying both parts of the country (these are those critical of the president's handling of the crisis). I return to these visual elements in chapter 3. What follows is a short description and visual of each of the five posts selected from the president's Facebook page.

What follows is a short description and visual of each of the five posts selected from the president's Facebook page. 


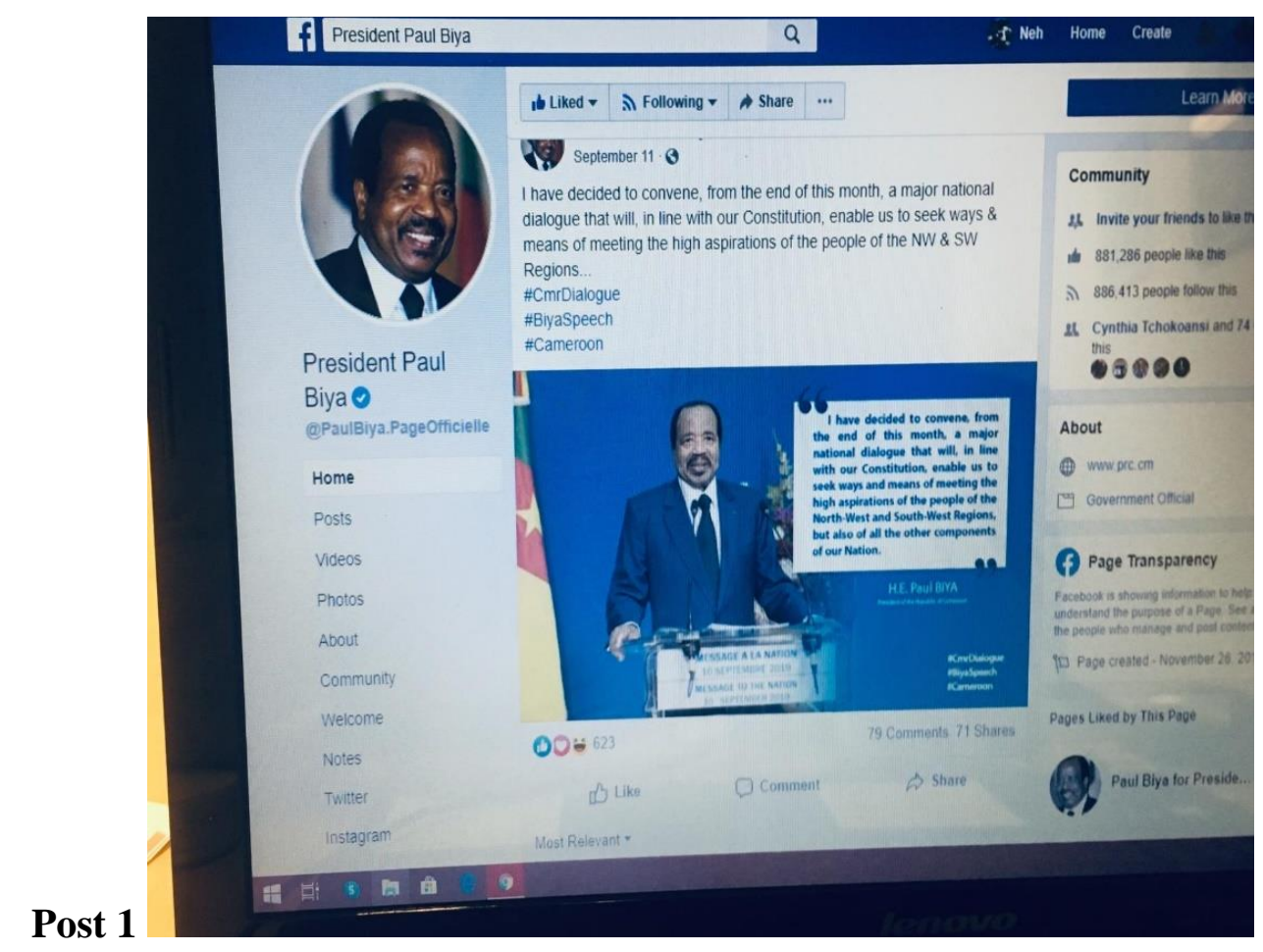

pertains to when the president communicated his intention on how he intends to address the crisis in the country. In this post, the president also mentioned his intention to have a Major National Dialogue starting September 30 to October 4.

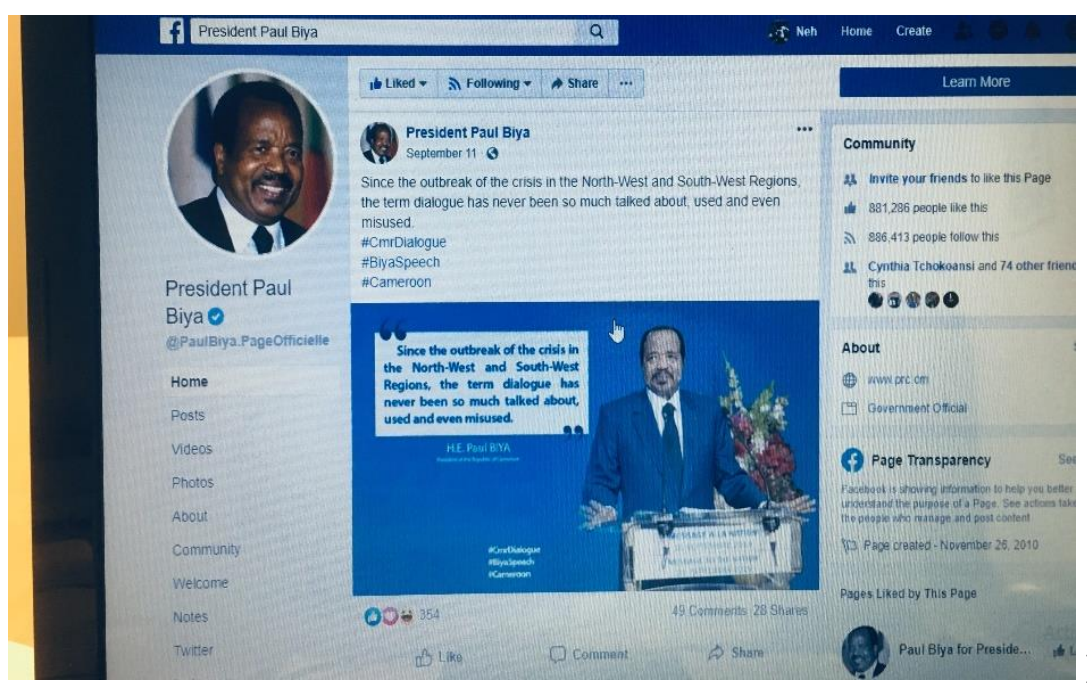

to when the president made mention of the fact that since the crisis started, there has not been a word so overused as the word "dialogue". 


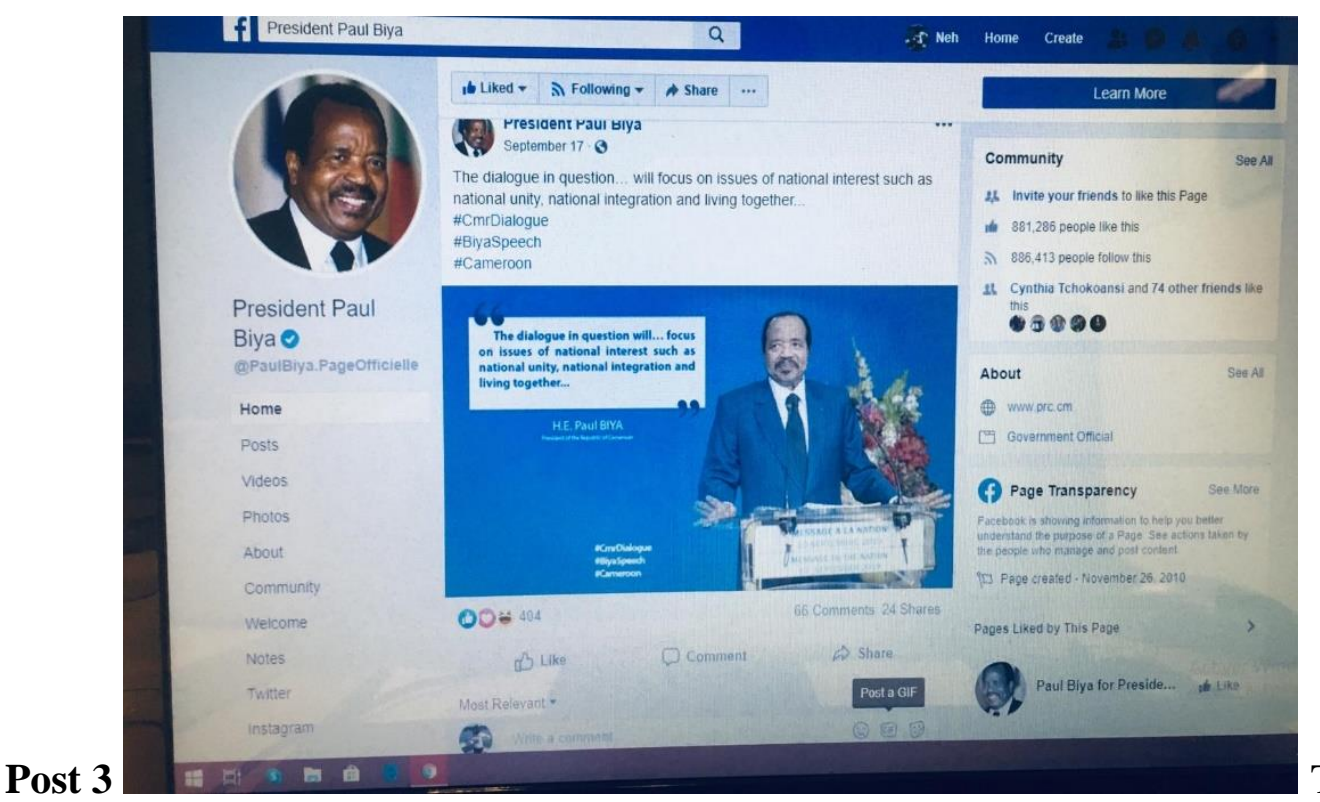

This post

captures what the president considers to be important issues for the Major National Dialogue, namely: national interest, national unity, national integration, and living together.

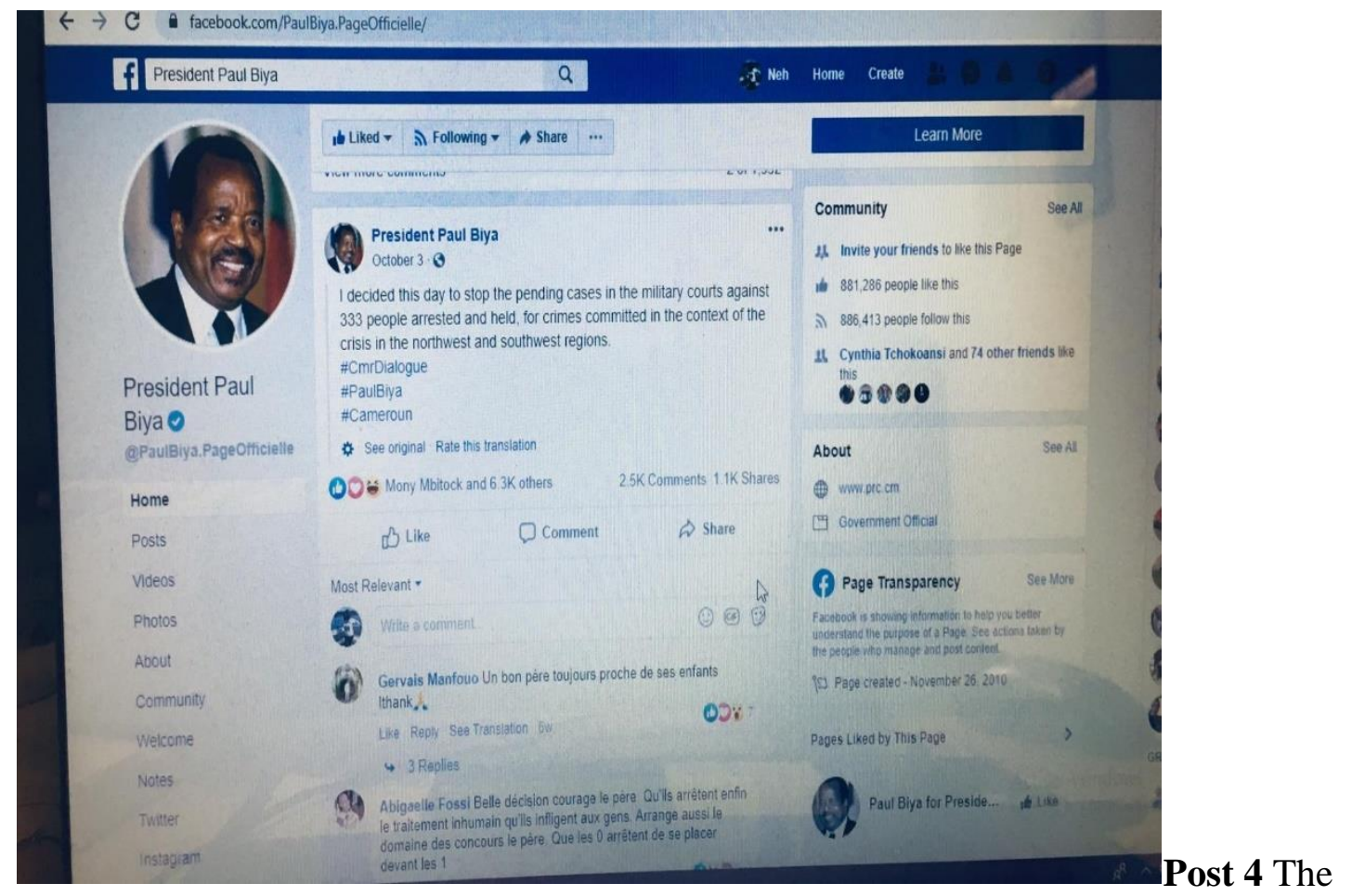

post communicates the president's decision to discontinue all proceedings pending in the military tribunal against three hundred and thirty-three people accused of crimes committed in the context of the Anglophone crisis. 


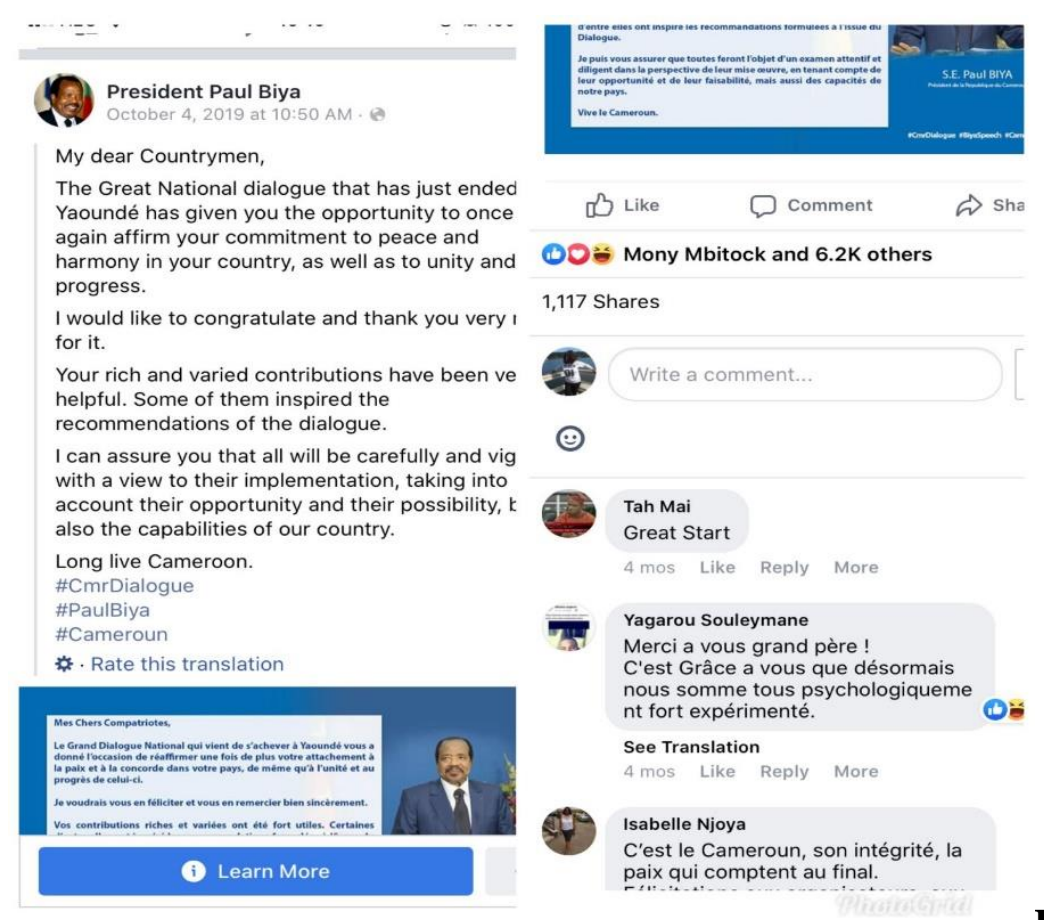

Post 5: This post is a congratulatory message by the president at the end of the dialogue. The president expressed his appreciation to citizens for their efforts to maintain peace and harmony in the country.

\subsubsection{Description of Artifact 2: Activist Mark Bareta's Facebook Posts}

Mark Bareta has over 150,000 followers. His Facebook page consists mostly of information concerning the ongoing Anglophone crisis in Cameroon. Also, his page consists of numerous posts on and about the crisis because Anglophone activists tag him to their publications about the Anglophone phone. Bareta's Facebook page is an online platform that rallies mostly secessionists. I will be using one post from the activist's page which received numerous reactions and comments from Anglophone activists and addresses the crisis in different ramifications. Unlike the brief posts published on the president's page, those found on Bareta's page are lengthy. This is the reason I am using one post only for my analysis. The post is four-hundred and seventy-eight words long, 
and it has one-hundred and forty-five comments in addition to five-hundred and eightythree likes. Below is a visual of Bareta's post. Following the post is Table 1 which presents a summary description of president Biya's and Bareta's Facebook.
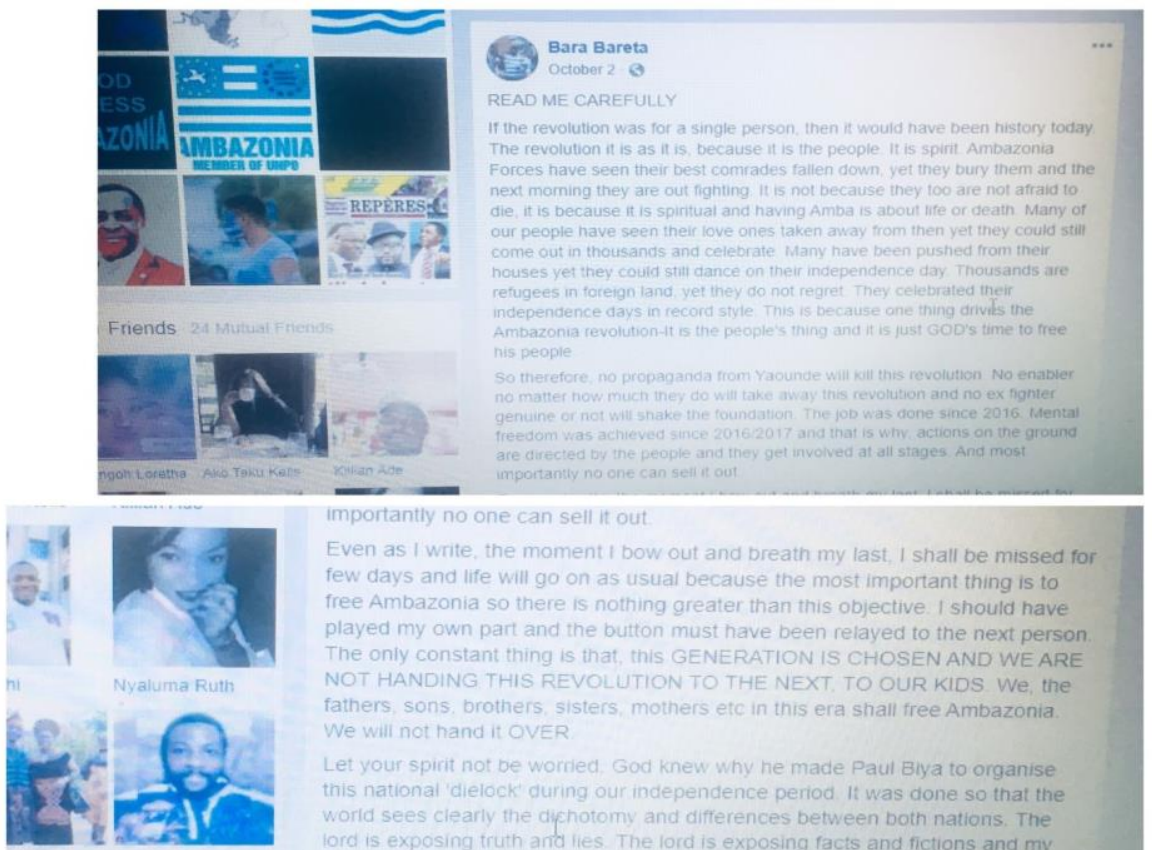

Even as I write, the moment I bow out and breath my last, I shall be missed for few days and life will go on as usual because the most important thing is to free Ambazonia so there is nothing greater than this objective. I should have played my own part and the button must have been relayed to the next person. The only constant thing is that, this GENERATION IS CHOSEN AND WE ARE NOT HANDING THIS REVOLUTION TO THE NEXT TO OUR KIDS We, the fathers, sons, brothers, sisters, mothers etc in this era shall free Ambazonia ve will not hand it OVER et your spirit not be wornied. God knew why he made Paul Blya to organise this national 'dielock' during our independence period It was done so that the world sees clearly the dichotomy and differences between both nations. The ord is exposing truth and fies. The lord is exposing facts and fictions and $\mathrm{my}$ people the world has seen EJOICE AMBAZONIA IS FREE

\section{Bareta's post}

NOTE: this is a single post; the entire post could not fit into a one screenshot, so two shots were combined.

Table 1: Summary description of president Biya's and Bareta's Facebook posts

\begin{tabular}{|c|c|c|c|c|}
\hline $\begin{array}{l}\text { Posts } \\
\text { analyzed }\end{array}$ & $\begin{array}{l}\text { Date } \\
\text { published }\end{array}$ & Word-count & $\begin{array}{l}\text { Number of } \\
\text { Comments }\end{array}$ & $\begin{array}{l}\text { Number of } \\
\text { Likes }\end{array}$ \\
\hline Biya Post 1 & September 10 & 57 & 2000 & 6500 \\
\hline
\end{tabular}




\begin{tabular}{l|l|l|l|l}
\hline Biya Post 2 & September 11 & 28 & 49 & 354 \\
\hline Biya Post 3 & September 17 & 30 & 157 & 1100 \\
\hline Biya Post 4 & October 3 & 20 & 284 & 2000 \\
\hline Biya Post 5 & October 4 & 102 & 1000 & 6200 \\
\hline Bareta's Post & October 4 & 478 & 145 & 583 \\
\hline
\end{tabular}

\subsection{Data Analysis}

In the preceding sections of this chapter, I described the procedure for the method of analysis in this study. I also described the data and data collection process. In this section, I apply the procedure for cluster method to the data collected. I begin my analysis with President Biya's posts (which I described in the previous section).

Post 1 consists of president Biya's intent to hold a national dialogue to address the Anglophone problem. The president asserted:

"I have decided to call, from the end of the current month, a great national dialogue that will allow us, within the framework of our constitution, to consider ways and means to respond to the deep aspirations of the peoples of the northwest and South-West, but also of all the other components of our nation." (Paul Biya, September 10, 2019) 
Burke asserts that, to identify clusters and key terms, the critic should find "what goes with what" (Burke, 1941). Applying the procedure for identifying key terms in a cluster analysis, the major key term identified in this post is "dialogue." This key term is clustered with another term "respond." The term "respond" in the context of this post, has to do with talking together to address the issue at hand. Clearly, the key term "dialogue" is repeated using the term "respond." As such the "god" and/or "good" term in the case of the president's use of rhetoric in this post is "dialogue." This term clearly communicates the president's rationale for convening the national dialogue. I return to this key term as I analyze three other posts from the president's page. Meanwhile, in a reply to this post, one Anglophone activist commented:

“His excellency please don't send your rude and arrogant ministers such as those who added fire to the already burning flames when $u$ send to talk to trade union leaders in Bamenda. Send ministers with good intentions and heart."

This comment expresses the desire for this activist commentator to see a peaceful resolution of the crisis, but at the same time indicates the distrust activists have on government officials appointed by the president who are also members of the national dialogue forum. It is important to note that this thesis is not analyzing comments under the posts collected for this study. The comments are only integrated into discussions of the artifacts to provide additional context and relevance to the rhetoric of the two actors being analyzed in the thesis. I also address the importance of comments accompanying posts in the "direction for further research" section in chapter 5. 
Post 2, the president stated that,

"Since the outbreak of the crisis in the North-West and South West Regions, the term dialogue has never been so much talked about, used and even misused." (Paul Biya, September 11, 2019)

In this post, the president again used the key term "dialogue.” This usage clearly demonstrates the frequency of the term. In the first post analyzed, the key term also emerged. I also identified another key term in this post, which is, "Crisis" based on the intensity of its usage in this post as it directly points to the reason why the key term "dialogue" is used (As we will see in other posts, the terms that cluster with "crisis" are "crimes" and "people"). Meanwhile, the term "crisis" as used by the president in this post can be referred to as the "devil" term because it represents the ongoing war in the country and is the exact opposite of the key term of "dialogue" which the president will otherwise want to communicate in with greater intensity. I pay attention to the key term of "Crisis" as I look at the next post.

Post 3, the President points out that,

"The dialogue we are talking about... will address issues of national interest, such as national unity, National Integration, living together...." (Paul Biya, September 17, 2019)

The key term in this brief post, again, is "dialogue" and president Biya relates the term "dialogue" to other important issues to be addressed. It is easy to see how the terms "national interest," "national unity," "national integration," and "living together" cluster 
around the key term "Dialogue." Furthermore, the fact that the president uses the term "dialogue" once more in this post to evoke the terms of national interest, national unity, national integration, and living together, in a context in which secessionists and other separatist activists are drumming support for the two Anglophone regions to break-away from the rest of the country supports the rationale of the key term to be identified as representing a god term and/or a good term for the president as a rhetor. This also depicts the intensity and frequency of key term while at the same time, conveying the key term's significance for the rhetor - the president.

Reading through the threads replying to this post, I found an intriguing comment from an Anglophone activist,

"hahaa are we not already integrated? Do we have problems living together? Again, we must accept the problem, see it as it is and solve it." This comment is from an Anglophone activist who mimics the president's intention towards reconsolidating the country as it was before the crisis. This is because the Anglophones activists are determined to completely secede from French speaking Cameroon.

Post 4, the president states that,

"I have decided to stop pending proceedings before the Military Tribunals against 333 people... detained for crimes in the context of the crisis in the North West and Southwest regions." (Paul Biya, October 3, 2019) 
Again, in this post, "Crisis" emerges, further demonstrating its frequency and intensity in the president's messaging. It is also important to note that the key term "Crisis" is used by the rhetor (the president) in a negative situation which emphasizes why I refer to this term as a devil term. It is important to note that key term "crisis" is used in conjunction with the term "crimes." The "people" a noun-term is also important because it is used pejoratively (negatively) by the president. Recall that the "people" referred to in this post were Anglophone protesters and other individuals randomly rounded up by the military during demonstrations. By linking the "people" to "crimes" relating to the "crisis," the president clearly clustered these terms together and reflects his devil term (in this post). Clearly, "crimes" and "people" will cluster with the key term "crisis" in the context of their usage in this post by the president.

Post 5 reads:

"My dear Countrymen,

The Great National dialogue that has just ended in Yaoundé has given you the opportunity to once again affirm your commitment to peace and harmony in your country, as well as to unity and progress. I would like to congratulate and thank you very much for it. Your rich and varied contributions have been very helpful. Some of them inspired the recommendations of the dialogue. I can assure you that all will be carefully reviewed with a view to their implementation, taking into 
account their opportunity and their possibility, but also the capabilities of our country. Long live Cameroon." (Paul Biya, October 4, 2019)

In this post, the president makes mention of the term dialogue once more and associates the term with nouns such as "peace," "harmony," and "unity." As such, terms that cluster with Dialogue in this post are "peace," "harmony" and "unity." This reifies the term dialogue as a god and/or good term. Burke (1941) notes that "ingredients composing a cluster...could be treated as representing the rest" (p.27). This further supports the reason why dialogue represents a god term.

As already mentioned, this post received a lot of reaction from Anglophone users; I found it interesting that Francophone Cameroonians commented on this post more than Anglophone activists. Two intriguing comments from an Anglophone and a French speaking Cameroonian respectively were:

"H.E. you were at least for once supposed to address the Nation and NW/SW population in particular in English. You speak English very well that I know." (Anglophone Cameroonian)

This comment demonstrates that the president, in his attempt to unite the two parts of the country, still neglects the dual heritage of the bilingual nature of the country (Fonkoué, 2019). The President has never given a state of the nation address in English since being in office in 1982. Moreover, the president stated earlier in his post published on September 10 (which I have analyzed in this study) that there is need, "to respond to the deep aspirations of the people of the northwest and South-West West," but, he addressed the Anglophones in French. It should be recalled that, the overuse of French in Cameroon 
was one of the major reasons which led to the strike action by the Anglophone lawyers and teachers as mentioned in chapter one.

A second compelling comment from this post was from a French speaking Cameroonian. He notes that:

"Dans votre propre discours vous avez exclu les Camerounais d'expression anglaise car il etait substantiellement adresse a eux et apres votre discours en Francais vous etes retournes vous asseoir laissant le soin a Mr Essoka de traduire en anglais. N'est ce pas la une forme de marginalization pure et simple?" (Francophone Cameroonian)

A loose translation of this comment in English will read,

"In your own speech you excluded the English-speaking Cameroonians because it was addressed to them not by you and after your speech in French you went and sat down leaving Mr. Essoka to translate into English. Is this not a form of outright marginalization?"

From this comment, it can be deduced that, French speaking Cameroonians have also acknowledged that the Anglophone Cameroonians are marginalized in a country where both regions are supposed to have equal rights. This also portrays the fact that French speaking Cameroonians look forward to the president as the decision maker of the country to pay heed to the petition of the Anglophone Cameroonians for peace to be restored in the country. 
Table 1 captures the key terms and clusters that emerged from president Biya's messaging as found on his Facebook page. In the next section, I analyze Bareta's post.

Table 2. President Biya's clusters

\begin{tabular}{l|l}
\hline Key Terms & Cluster Terms \\
\hline Dialogue (God term) & $\begin{array}{l}\text { national interest, national unity, } \\
\text { national integration, living together, } \\
\text { peace, harmony }\end{array}$ \\
\hline Crisis (Devil term) & Crimes, people \\
\hline
\end{tabular}

\subsubsection{Mark Bareta's Facebook Posts}

I chose only one post for my analysis from Bareta's Facebook page for reasons already explained in this chapter. This post was published by Bareta on October 02, 2019. The post below is that which I selected from the activist's Facebook page for my analysis. The post is four hundred and seventy-eight words long. The post reads:

"If the revolution was for a single person, then it would have been history today. The revolution it is as it is, because it is the people. It is the people. It is the spirit. Ambazonia Forces have seen their best comrades fallen down, yet they bury them and the next morning they are out fighting. It is not because they too are not afraid to die, it is because it is spiritual and having Amba is about life or death. Many of our people have seen their love ones taken away from them yet they could still come out in thousands and celebrate. Many have been pushed from their houses yet they could still dance on their Independence Day. Thousands are refugees in foreign land, yet they do not regret. They celebrated their 
independence days in record style. This is because one thing drives the Ambazonia revolution. It is the people's thing and it is just GOD's time to free his people.

So therefore, no propaganda from Yaoundé will kill this revolution. No enabler no matter how much they do will take away this revolution and no ex fighter genuine or not will shake the foundation. The job was done since 2016. Mental freedom was achieved since 2016/2017 and that is why actions on the ground are directed by the people and they get involved at all stages...the most important thing is to free Ambazonia... The only constant thing is that, this GENERATION IS CHOSEN AND WE ARE NOT HANDLING THIS REVOLUTION TO THE NEXT, TO OUR KIDS. We, the fathers, sons, brothers, sisters, mothers etc. in this era shall free Ambazonia. We will not hand it OVER. Let your spirit not be worried. God knew why he made Paul Biya to organize this national 'dielock' during our independence period. It was done so that the world sees clearly the dichotomy and differences between both nations...REJOICE AMBAZONIA IS FREE." (Mark Bareta, 2019).

The key terms which I identified in Bareta's post are "revolution" and "Paul Biya". The term "revolution" emerges as the god term for this activist while "Paul Biya" is the devil term. I discuss these key terms separately. First, it should be recalled that Foss (2018) notes that key terms are contingent upon frequency and intensity. "Revolution" as a key term is mentioned in six instances, and the term's intensity emerges from other terms that cluster with the key term. In other words, the key term of "revolution" invokes 
or brings into the present the other terms. Clearly terms that cluster with "revolution" are "people", "independence", "freedom", "God" and "Ambazonia" (Ambazonia is the name the independence movement has given to Anglophone Cameroon). It is intriguing to see how as a god term, one of the terms that clusters with "revolution" is God. While "people", "independence", "freedom", and "Ambazonia" might understandably be seen as terms that cluster with revolution because people fight for a revolution, independence and freedom are the obvious ends of the revolution, and Ambazonia, the ultimate goal of the revolution, to invoke "God" in the revolution is compelling as the activist positions the revolution as ordained by God (similar to "manifest destiny" in America's historic territorial expansion). God is the supreme being, and Cameroonians have a strong spiritual attachment to God, the creator of humanity (at least in the context of religion). To invoke God in a way that the term "God" clusters with the activist's "god term" of "revolution" is indeed both compelling and expedient on the part of the activist compelling because it is a powerful persuasive language capable of swaying not only secessionists but also undecided Anglophone Cameroonians in regard to the so-called "revolution". By associating God to the revolution, Bareta appeals to the highspiritedness of Ambazonians or Anglophone Cameroonians. As far as expediency is concerned in the context of this post, Bareta, as a rhetor, could be spewing rhetoric solely convenient to achieving his goals of an independent and freed Ambazonia state.

The devil term for this activist as mentioned earlier is "Paul Biya". This too is an intriguing finding from the analysis. Paul Biya is the president of Cameroon. For the president to emerge as the devil term in this post conveys the activist's disgust at the 
entire government of the nation with Paul Biya as the commander-in-chief. This disgust is clearly demonstrated with the terms that cluster around "Paul Biya", namely, "Yaounde" (Yaounde is the political capital of Cameroon and the seat of Paul Biya's power), "propaganda", "kill”, and "dielock” (“dielock” is a derogatory or pejorative reference to the national "dialogue" which the president convened). As devil term, "Paul Biya" represents propaganda, a killer, and Yaounde, the seat of the propaganda and "killing ideology" that has led to the death of what the activists refers as "our comrades" (i.e., separatist fighters). Table 2 illustrates the key terms and clusters that emerged, as well as the god term and devil terms for the activist.

Table 3. Mark Bareta's clusters

\begin{tabular}{l|l} 
Key Terms & Cluster Terms \\
\hline Revolution (God term) & $\begin{array}{l}\text { Ambazonia, independence, people, } \\
\text { freedom, God. }\end{array}$ \\
\hline Paul Biya (Devil term) & Propaganda, kill, dielock, Yaounde. \\
\hline
\end{tabular}

Berthold (1976), mentions that, clusters and agons work similarly in rhetorical criticism. Nonetheless, agons function best to illustrate opposite terms in clusters. As a result, unlike the president's page wherein he advocates for peace, harmony and unity, Bareta advocates for secession for peace to prevail. I should point out that while the president uses the term "crisis" in his posts as a negative term and exigency to be addressed, Bareta applies the term revolution as something good for Anglophone Cameroonians. Clearly, in Bareta's case, the key term "revolution" has a positive connotation for Anglophone Cameroonian activists. Drawing from Berthold (1976), the 
use of such terms are agons because, crisis and revolution both have opposite meanings to the rhetors, that is president Biya and Bareta. Moreover, Berthold (1976) points out that, "[o]pposition may also be expressed by describing a form of competition between two terms." As a result, the terms "crisis" and "revolution" used by president Biya and Bareta respectively demonstrate a form of rivalry as both rhetors are advocating and inciting two different ideas - that is peace from president Biya's standpoint and secession from Bareta's.

\subsubsection{Visual elements of artifacts}

While this study did not initially set out to analyze the visual elements of the artifacts, when analyzing the written Facebook posts, my attention was drawn to the role of visual elements in Biya's and Bareta's rhetoric. As already mentioned in the sections that describe the artifacts in this study, different emojis (e.g., laughing, smiley, angry, heart, and like or "thumbs up") were used by followers on president Biya's and Bareta's posts respectfully. In addition to the emojis, the president's posts were accompanied by a picture of himself, including his profile picture. For Bareta, the visual elements that accompanied his written posts in addition to the 'likes' and a profile picture was the Ambazonian flag. It is important to note that Bareta's profile picture at the time the post was screenshot, was that of the self-proclaimed president of Ambazonia. In looking at these visual elements, I begin with the president's posts.

I determined that the pictures that accompanied the president's posts may have been to give the impression that the president himself is in-charge of the situation and concerned about the crisis and well-being of all Cameroonians. The smile on his face on 
all the pictures apparently conveys the president's hope or optimism for the outcome of the dialogue and future handling of the crisis. Same connotation might apply to the president's profile picture in which he is all smiles. However, these visual elements can also have a denotative meaning separate from the connotative meaning. At face value (denotive meaning), we see a president who is smiling to his public. The smile appears friendly and inviting for followers.

The emojis on the president's posts included "heart", "thumbs up", “angry", and "laughing". It is possible to deductively explain that the "heart" and "thumbs up" emojis were from followers who are supportive and adhere to the president's worldviews, as well as individuals pleased that the president has decided to convene a national dialogue. The "angry" and "laughing" emojis might convey a sense of anger and mockery from persons who think the president was failing the country by not doing the "right thing" releasing all persons arrested in connection to the crisis before calling for a national dialogue.

Meanwhile, the Ambazonia flag and the profile picture of the self-proclaimed president of Ambazonia that appeared on Bareta's post could convey his ties, commitment and love for the "revolution" which he sees as ordained by God. The message will definitely portray Bareta to his followers as a fighter for the revolution and could also inspire individuals standing on the sidelines of the "revolution" to become committed followers. However, there might also be another layer of meaning to the flag and profile picture on Bareta's page. As one of the frontline activists on the Anglophone crisis, Bareta solicited material support from people sympathetic to the Anglophone 
struggle for funding of people who are "defending" Ambazonia on the ground. Making the picture of the Ambazonia self-proclaimed president as his profile picture, and by including the Ambazonia flag on his page, could be a form of political expediency on the part of Bareta - so that more material support or contributions could be made to the Ambazonia "revolution".

On the emojis, there were many more "thumbs up" and a few "angry" emojis. Deductively, the "thumbs up" were from supporters and sympathizers of the "revolution" and die heart followers of Bareta. These are people who agree with the revolution discourse and secessionist logic. The angry emojis could be from individuals supportive of the president of the nation, and or from other splintered secessionist groups competing for recognition in the Anglophone crisis. As at the time the national dialogue was convened, there was already fractures within some secessionist camps as some individuals thought the national dialogue might be worth giving a try.

Overall, the visual elements from the artifacts discussed convey what appears to be the denotative and connotative rhetorical meanings accompanying the Facebook posts. Significantly, the visual elements add context to the discourses on and about the Anglophone crisis. The visual elements add to the meanings and interpretations I was able to make on the narratives that emerged from the analysis in this study. While a more complete visual analysis is beyond the scope of this study, by paying attention to these visual elements in the artifacts in this study, a holistic picture of my analysis emerges. 
In this chapter, I have described and discussed the procedure for cluster analysis as a method of rhetorical criticism. I also described the data used in this study and explained the data collection process. Specific artifacts used in the study were also discussed. I also analyzed the artifacts by identifying key terms and terms that clustered with the key terms. I explained how key terms and clusters emerged from the artifacts. I also looked at the visual elements accompanying the artifacts.

In chapter 4, I focus on the research questions guiding this thesis by answering the questions and providing interpretations of the findings. 


\section{Findings and Interpretation of Results}

\subsection{Introduction}

Chapter 3 discussed the method for conducting the analysis in this study; described the data and data collection process and did the analysis of the data collected. In this chapter, I will be answering two research questions that guided this study based on the analysis conducted in chapter 3 .

\subsection{Answering Research Questions}

Following are research questions for this study:

RQ1. What are the descriptive narratives that emerge from the actors?

RQ2. What do these narratives tell us about the actors' motives?

\subsubsection{RQ1. Narratives from president Biya's Rhetoric}

Two major narratives emerged from president Biya's rhetoric on the Anglophone crisis. The narratives were captured in the key term and the terms that clustered around the key term. Clearly, by looking at the key term (DIALOGUE) and paying attention to the other terms that clustered around the key term of Dialogue, I was able to determine several narratives that framed the president's rhetoric on the crisis. I discuss the narratives below:

\section{Narrative of National Unity}

This was an underlying narrative that framed the president's rhetoric on the crisis. The narrative of national unity was repeatedly evoked in all five posts by Paul Biya. Drawing 
the public's attention to the need for all Cameroonians (Anglophones and Francophones) to "living together" and promote "national integration", the president spoke directly to the narrative of national unity. The "National Dialogue" was convened in the first place to seek ways of preserving this national unity that was already been threatened by separatists. In convening this dialogue, the president stated that the forum is an opportunity "to consider ways and means to respond to the deep aspirations of the peoples of the Northwest and South-West, but also of all the other components of our nation" (Biya, September 10, 2019). The "deep aspirations" in this statement refer to what might have triggered the crisis. The president was thus communicating the utmost importance of recovering the country's unity by seeking ways of fixing and resolving threats to the national integration. As evoked in his posts, the president's narrative of national unity clearly positioned "national unity" as an issue of "national interest", suggesting that national unity must be guaranteed at all cost and ideals of national unity must be promoted through "living together" (see Post \#3).

\section{II. 'Peace' Narrative}

This narrative was also frequently evoked. Linked to the narrative of national unity, the peace narrative emerged in the president's rhetoric on the crisis through the term "harmony". The term "harmony" is one of several terms that clustered around the key term of "dialogue" and conveys the president's desire for peaceful coexistence between Anglophones and Francophones. At the same time, several rhetorical actions which the president took and mentioned in his posts were aimed at pushing the peace narrative to the public. For example, the president mentioned the discontinuance of all pending 
proceedings in the military tribunals against 333 people detained for crimes in the context of the crisis in the North West and South West regions. This action was rhetorical because it communicated the president's intention in response to outcry from affected communities to have all persons detained in connection to the crisis released. It was not a blanket "clemency" - but a rhetorical action intended to push the president's peace narrative. Furthermore, the peace narrative was again pushed to the public when the president clearly appealed to the public to be committed to peace and congratulating participants at the dialogue forum for taking steps to ensuring that peace returns to the country.

The frequency and intensity of these two narratives -the- narrative of national unity and the peace narrative - suggest that these narratives were of most significant to the president. In his closing statement following the conclusion of the national dialogue forum, the president re-evoked these narratives, as he created a post in which he not only thanked participants, but also reiterated his commitment to follow through the recommendations of the forum, and then, ending the post with the words "Long Live Cameroon" (again, reinforcing the narratives of national unity and peace).

\subsubsection{RQ1. Narratives from activist, Bareta's Rhetoric}

From the analysis conducted in chapter 3, I find one underlying narrative that emerged from Bareta's rhetoric - the narrative of secession or separation. Like Biya's narratives, Bareta's narrative emerged from the key terms and terms that clustered around the key terms. The narrative of secession was clearly evoked in Bareta's "god term" of "revolution" and by exploring terms that cluster around the key term, it was even more 
visible to see how the narrative of secession emerged. Bareta repeatedly evoked the terms Ambazonia, independence, and people. Ambazonia is the name given to the "new" nation they sought to create should Anglophone Cameroon secede from Francophone Cameroon. Ambazonia makes explicit the narrative of secession and "independence" is the means through which the nation of Ambazonia will come into existence; for this to happen, the "people" must be fully involved in the "revolution", against Bareta's "devil", Paul Biya. Furthermore, by associating Paul Biya with terms such as "dielock", "propaganda", and "kill", and "crimes", Bareta makes his narrative of secession even more compelling to his followers and sympathizers as Paul Biya is portrayed as the "devil" standing between the "people" and their "promised land". The narrative of secession, thus, emerges from key terms (god term and devil term) as well as from the terms clustering around the god and devil terms.

\subsubsection{RQ2. What do these Narratives tell us about the Actors' Motives?}

Burke notes in his Grammar of Motives that each dominant term corresponds to a particular worldview of the rhetor and that the worldview can point to the motive of the rhetor. In this thesis, the narratives discussed while answering RQ1 in this chapter provide strong indicators to the motives of the two rhetors in this study. One strength of cluster analysis as a method of rhetorical criticism is that clusters of terms can point to the motives of the rhetor, thus, the intensity of clusters is seen in its ability to make use of the rhetor's own words to determine the rhetor's motive. This is significant because Burke (1969) thinks the "use of language" can induce "cooperation" in humans because humans "by nature respond to symbols" (p. 43) and language is symbolic. This points to 
the idea that a rhetor's discourse has motives and the discourse itself is the site where we can uncover the motives of the rhetor if we pay careful attention to the words or language used in the discourse by the rhetor. In so doing we can understand 'how particular realities' come into being and how texts thus motivate or block particular understandings, attitudes, and pre-dispositions" (Foss, 2018, p. 368). The narratives by Cameroon's president, and the Anglophone activist, Bareta, point to their motives in connection to the crisis. Looking at the different narratives that emerged from this analysis, I make the following determinations on Biya's and Bareta's motives:

(a) President Paul Biya's motive is to demonize secessionists and sway the Cameroonian people into embracing a stronger national unity and promoting peaceful coexistence in united country. In doing so, the president portrays secessionists as criminals, and their ideology as destructive to national unity, peace, and national integration. The president's "god term" of dialogue and his "devil term" of crisis justify this interpretation of his motive. From the president's narratives which emerged from the key terms (god term and devil term) and terms that cluster around the god term and devil term we see the sharp contrast in his rhetoric between his ideals and his portrayal of secessionists.

(b) Mark Bareta's motive is to stir up resistance and keep the momentum growing among Anglophones (particularly those who endorse the secessionist ideology) against the current government and all that Biya's regime represents for the ultimate goal of an "independent Ambazonian state". Bareta's god term 
(revolution) and devil term (Paul Biya) tell of his motive. Paul Biya and his government are demonized, in contrast to the persuasive appeal made on the "revolution". For Bareta, "people" are freedom fighters while for Biya, "people" (those subscribing to the "revolution").

To sum up this section, it is important to note that the narratives emerged out of analysis of the artifacts in this study (including an examination of the key terms - god term and devil term - as well as the terms that cluster around the key terms. By further looking at the narratives, as a rhetorical critic, I was able to make determinations of the motives of the rhetors in this study. The determinations were made following the logic of frequency and intensity of the key terms and clusters in Biya's and Bareta's posts on and about the Anglophone crisis.

In chapter 5, I discuss some trends that emerged during the analysis phase of this study; offer recommendations toward possible resolution of the ongoing Anglophone crisis based on the findings of this thesis; discuss limitations of the study; suggest direction for further research; and draw a conclusion by way of summarizing the thesis. 


\section{Discussions and Conclusion}

\subsection{Introduction}

Chapter 4 reported the findings of this study. The two research questions guiding the study were answered and discussed. In this chapter, I wrap up my thesis by looking at some emerging trends in the analysis conducted, and then a discussion of recommendations, limitation of study, direction for further research and a concluding summary of the entire thesis.

\subsection{Discussions}

In the following paragraphs, I discuss some intriguing trends that further help provide a broader view on the findings in the study. To clarify, I discuss these trends in this chapter and not in chapter 4 because I didn't want to lessen the focus on the findings. I wanted the findings to standout.

First, as I immersed myself into the texts, and identifying key terms, I noticed the power dynamics that were at play in the discourse on the Anglophone crisis. The power dynamics are directly related to the use of social media. While it is true that a nonwestern context like Cameroon has a high power distance dimension (c.f. Hofstede, 2011) which basically explains the degree to which people accept as normal the power wielded by those in positions of power (for example, the president of the country versus the local people), social media is disrupting this power distance. To understand the dynamics of power distance in non-western contexts as compared to western contexts, suffices to look at the use and role of social media in less democratic contexts. Social 
media helps to reconfigure political spaces in less democratic nations. Social media afforded the opportunity for an activist like Mark Bareta and other Facebook users to speak directly to power - Paul Biya. In recent past, citizens could not directly respond to, or make a comment in reply to the president of the nation, to disagree, or express contrary opinions, as such political spaces were completely inexistent. But in contemporary Cameroonian society, citizens are not only afforded this opportunity to speak to power but look up to social media to speak to and hold power accountable. In fact, I should point out that if the Anglophone crisis degenerated into an armed conflict, it was largely the result of the heavy presence of secessionists activists on social media. It is this visible power of the social media to disrupt and reconfigure the political space in the context of Cameroon that activists like Bareta and other social media users have referred to the Anglophone crisis as a war that is fought and won on social media. The actions which Cameroon's president took - including the convening of the National Dialogue and the release of some persons whose criminal proceedings were pending in the courts in connection to the anglophone crisis - was arguable the result of pressure put up by activists on social media. Moreover, in the past, Cameroon president's presence on social media was nearly absent, such that when he sent out a tweet or made a post, it was almost seen as something new to the Cameroonian public. But, with increased pressure around the Anglophone crisis occurring primarily on social media, the president's presence on social media drastically increased - thus, acknowledging the power of social media. While the president clearly wields power to make decisions in a dictatorial manner, that power is now being challenged on social media, as important decisions by the president 
on and about the Anglophone crisis are taken to apparently address narratives that occur on social media.

Second, the analysis in this study indicates that the ongoing Anglophone crisis has actors with different motives, and these motives are informed by the narratives individual actors pushed to the public in support of the cause they are pursuing. President Paul Biya positions himself as someone wanting "unity" and "peace" in the country, while Bareta pushes a narrative of secession. Informed by their "god terms" and "devil terms", the rhetors in this study have motives that clearly align with the narratives they hold on the crisis. One strength of cluster analysis as a method of rhetorical criticism is its ability not only to uncover narratives, but also to reveal motives (or worldviews). The rhetors' own words are used to make determinations on narratives and motives.

I offer another look at the "god terms" and "devil terms" by way of discussing some intriguing observations. For Paul Biya, "crisis" is his devil term and clusters with "people" and "crimes". It is intriguing that "people" that is, Anglophone Cameroonians involved in the Anglophone crisis clusters with Biya's “devil term"; Biya frequently refers to separatists fighters as terrorists and criminals in documents that are beyond the scope of this research (c.f. Biya, 2017). To characterize "people" as devils could represent Biya's disgust for individuals clamoring for separation, and this could also point to some insights on Biya's worldview in regard to the Anglophone crisis. It might even not be wrong to point out that this disgust for "people" (separatists) is the reason why Biya opted for a military solution (which has so far remained unsuccessful in resolving the crisis). To see "people" as terrorists and criminals, is tantamount to 
wanting to exterminate those "people." This logic has led to a wide outcry by secessionists who have long begin invoking accusations of genocide against the government on Anglophones. But even more intriguing is the fact that for secessionists (as uncovered in the analysis in chapter 3 and findings in chapter 4), Paul Biya is their "devil" and is represented by terms such as "kill”, "propaganda", and "dielock". By inference, Biya is synonymous to "killings", "propaganda", and an unproductive "dielock" (i.e., dialogue). This has largely influenced the narrative of the secessionists and driven secessionists to focusing on resisting anything that has to do with Biya and his government.

It is even more intriguing to see that Biya's god term is "dialogue" while Bareta's is "revolution". To have "dialogue" as a god term without the willingness to have an open dialogue with no pre-conditions is telling. In a document beyond the scope of this study, Biya insists that there will be no dialogue that involves discussions secession and even a federal system of governance (c.f. Biya, 2018). God terms convey what is desirable for the rhetor while devil terms point to the undesirable and are always in opposition to each other. At the same time, Bareta who largely represents the views of secessionists, has as god term "revolution". It is indeed interesting to see how secessionists point to their "revolution" as ordained by God. They see the "hand of God" in the revolution as discussed in chapter 4. I wanted to develop an interesting analogy in relation to the idea of "manifest destiny" a doctrine put forth by America in which they characterized their expansion into other territories as a mission ordained by God. This doctrine justified America's earliest territorial conquest in history. As I analyzed Bareta's post it was 
interesting to see that he made a similar argument noting that the revolution (secession) is ordained by God and has God's blessings. As mentioned in chapter 4, this is both compelling and expedient: a majority of Cameroon's population profess Christianity as their religion. For secessionists to invoke the "hand of God" in their "revolution" appears to be strongly persuasive; on the other hand, the secessionist motive for appealing to the "hand of God" could also be seen as expediency (as in political convenience). This aspect of the analysis reminded me of Burke's argument that while persuasion has historically been the focus of rhetoric, adding "identification" would help broaden our understanding of rhetoric. By trying to create a rapport with Anglophone Cameroonians (who are predominantly Christians) by invoking God into the "revolution" while also appealing to the "freedom" and "independence" of "Ambazonia" (see chapter 4), it is possible to see how the secessionists' position taps into both identification and persuasion.

\subsection{Recommendations}

Based on the findings in this thesis, the following recommendations may increase the likelihood that the crisis might be resolved as a political crisis rather than a military option as is currently the situation in Anglophone Cameroon.

1. The government should be willing to convene another open and frank dialogue with no pre-conditions. The national dialogue convened by Cameroon's president in October 2019 had pre-conditions: there was to be no discussions on the structure and form of state. Cameroon's president insisted that Cameroon was indivisible; therefore, calls from secessionists to hold a dialogue that will determine the structure of the state including outright secession or at the very least 
federalism were not welcomed. These preconditions are reasons why Bareta in his post referred to the national dialogue as "dielock" - a derogatory way of saying the national dialogue "died" or "locked" even before it was convened.

2. Looking at the narratives that emerged from the analysis in this study, Paul Biya clearly pushed narratives of "national unity" and "peace", and his motive uncovered in the analysis was evidently informed by his narratives on the crisis. These narratives and motives point to the president's desire for the country to remain united (undivided territorially), contrary to what secessionists wanted outright secession as seen in the narrative of secession pushed forth by the activist, Bareta. My recommendation here will be for the president to take steps that clearly show his desire for peace to be retained, and this may include releasing all Anglophone Cameroonians incarcerated in prisons across the country for their involvement in the secessionist movements. This is also the desire of the secessionist activists. Federalism as an alternative form of governance may help resolve the crisis. A ten-state federation (even as moderate secessionists want a return of the two-state federation following the 1961 plebiscite discussed in chapter 1) could help resolve the tension. The next section discusses limitations of this study.

3. Secessionist activists should also be willing to enter a dialogue without preconditions. This is important because while secessionists accuse the president of bad faith in setting preconditions, secessionists also fall into this same trap of insisting that the president must order the release of all persons jailed or sentenced 
in connection to the anglophone crisis before any open dialogue can hold - the president has remained adamant.

\subsection{Limitations}

The current research work has several limitations which, although not critical for the findings in this thesis, may be useful for future research. The first limitation has to do with the scope of the study. The study analyzed 6 posts, five of which were published by Cameroon's president, and one post published by the Anglophone activist (for reasons discussed in chapter 3). The scope also runs over a 4-month-period. Maybe if the scope of the study is expanded to include a longer timeframe and several more posts, some trends relevant to the study might be uncovered with analysis over a longer timeframe. The second limitation of the study appears to be the fact that comments accompanying posts may be good artifacts for analysis. I addressed this aspect in chapter 3 and in the next section of this chapter). However, the findings in this study are significant as they provide first steps towards understanding underlying narratives that inform the Anglophone crisis discourse from primarily two main opposing sides - the government versus the secessionists. The motives of the rhetors uncovered in this study definitely pave the way for potential recommendations for a political solution to the crisis. Clearly, the narratives on the crisis, and the motives behind the political discourse by the two rhetors uncovered in this thesis might help build on recommendations for a political resolution of the ongoing conflict. 


\subsection{Direction for Further Research}

This thesis reveals opportunities for continued research on cluster analysis as method of rhetorical criticism, as well as on the political discourse surrounding the Anglophone crisis. Walton's (2013) application of the method by not using god terms and devil terms, and rather focusing on themes that were clustered by terms and phrases was an eye-opener for me. While my study fully focused on god terms and devil terms drawing from the method's originator - Burke, and from others who operationalized the method, I thought future research could adopt a cluster approach that focuses on themes and not god term and devil terms. This is important because the struggle in search of a "neutral" term within rhetors' discourses will be more adequately addressed - more so, when analyzing the rhetoric of non-western actors, as was the case in my study. Nonwestern rhetors' rhetoric occurs in contexts largely different from western contexts. Such differences include but not limited to power dynamics. In non-western contexts with high power distance, rhetors in positions of power have little or no obligation to communicate in ways that show they are answerable to local people or grassroots. Also, the local people often accept as a normal, this power distance compared to western contexts with low power distance, even though this high power distance is getting reduced in contemporary non-western contexts through the use of social media - as the grassroots can speak directly to power just by replying to the president's Facebook post, tweeter account, or other social media platforms.

Further research could expand on analyzing the comments accompanying the Facebook posts of Cameroon's president, and the Anglophone activist. In this thesis, the 
focus was on a limited selection of posts selected for the thesis. I used a few comments in the analysis to provide additional context to the posts that were being analyzed. The comments were useful in further situating the rhetorical discourse around the larger political discourse by the two rhetors in this study.

Another direction for research could include expanding the timeline for the crisis so that the scope of the study is a little broader than that which define this current study. For example, this study analyzed posts published over a 4 months periods, and this was because of time constrained giving the deadlines for completing this thesis. If a rhetorical critic has a longer timeframe, future research could include analyzing posts published over a one-year period or longer since the crisis is ongoing for a little over three years now. This could help provide a broader picture of the rhetorical discourse on the crisis. At the moment, I am contemplating one or a combination of these aspects as potential areas of furthering my research for my $\mathrm{PhD}$ program and conferences.

\subsection{Conclusion}

This thesis has been an opportunity to work with a method of rhetorical criticism cluster analysis - to explore the different narratives on and about the Anglophone crisis by two prominent rhetors involved in the crisis. By so doing, I was able to make determination of the motives of the rhetors, thereby, answering the two research questions that informed and guided this thesis. Clearly, the first research question focused on the descriptive narratives that emerge from the actors in the crisis (Cameroon's president, and Activist, Bareta). The second research questions focused on the motives of 
the actors. Cluster analysis a method of rhetorical criticism - discussed by Burke but operationalized by scholars such as Foss (2018) and Berthold (1976), was applied to the artifacts (Facebook posts) in the study. The different narratives that emerged showed that Cameroon's president pushed the narratives of "national unity" and "peace", indicating his intentions to persuade Cameroonians, particularly those in the two English speaking regions of the country, to focus on a united country. On his part, the prominent Anglophone activist focused his rhetoric on the narrative of secession, aligning his narratives with his intention to have Anglophone Cameroon to secede. The narratives and motives emerged from examining key terms (god terms and devil terms) plus the terms that cluster around the god terms and devil terms respectively. Having identified the different narratives and motives of the rhetors, trends significant to the research conducted, recommendations on resolving the anglophone crisis, limitations of the study, and direction for further research were also discussed. This thesis has contributed to rhetorical theory by applying cluster analysis as method of rhetorical criticism to social media posts. This is indeed a novel area in the method's application. The outcome of this thesis suggest direction for further research, and I look forward to continuing developing the outcome of this thesis in other scholarly and professional contexts as I pursue my academic and career dreams. 


\section{References}

Angel, A. \& Bates, B. (2014). Terministic Screens of Corruption: A Cluster Analysis of Colombian Radio Conversations. Journal of Kenneth Burke Society, 10(1). Retrieved from http://kbjournal.org/angel_bates_terministic_screens_of_corruption

Anyangwe, C. (2008). Imperialistic Politics in Cameroun: Resistance and the Inception of the Restoration of the Statehood of Southern Cameroons. Bamenda, Cameroon: Langaa Research \& Pub. CIG.

Berthold, C.A (1976). Kenneth Burke's cluster-agon method: Its development and an application, Communication Studies, 27(40), pp 302-309

Bizzell, P., \& Herzberg, B. (1990). The Rhetorical tradition: readings from classical times to the present. Boston: Bedford Books of St. Martin's Press.

BringBackourInternet. (2018, March 1). Retrieved from,

https://www.accessnow.org/shutdown-ended-cameroonians-still-feeling-impact/

Burke, K. (1945). A Grammar of Motives. University of California Press.

Burke, K. (1950). A Rhetoric of Motives. Berkley and Los Angeles, California: University of California Press.

Burke, K. (1937). Attitudes Toward History. (2nd) ed. Vol (2). New York: The New Republic

Burke, K. (1966). Language as symbolic action: essays on life, literature, and method. Los Angeles California: University of California Press, LTD.

Burke, K. (1941). The Philosophy of Literary Form: Studies in Symbolic Action (3rd) ed. Louisiana State University Press.

Burke, K. (1941). The Philosophy of Literary Form. (3rd) ed. University of California Press Berkley and Los Angeles, California: University of California Press, Ltd.

Caldwell, M. (2017, January 31) Cameroon: colonial past and present frictions. Retrieved from

https://www.dw.com/en/cameroon-colonial-past-and-present-frictions/a-37344849

Dunn, H., Quinn, L., Cobridge J. S., Eldeirawi K., Kapella M., Collins, E.G (2018). Cluster Analysis in Nursing Research: An Introduction, Historical Perspective, 
and Future Directions. Western Journal of Nursing Research. 40 (11), pp. 16581676

Fonkoué, A. R. (2019). Nation Without Narration: History, Memory and Identity in Postcolonial Cameroon. Cambria Press.

Foss, K. S (2018). Rhetorical criticism: exploration and practice (5th) ed. Illinois: Waveland Press.

Hofstede, G. (2011). Dimensionalizing Cultures: The Hofstede Model in Context. Online Readings in Psychology and Culture, 2(1). https://doi.org/10.9707/23070919.1014

Jay, G. S. (1985). Kenneth Burke 1897-1993. Modern and Postmodern Rhetoric. Pp. 1295-1347.

Kindzeka, M.E. (2019, September 24). Cameroon's Separatists Intensify Attacks to Protest Dialogue. Retrieved from https://www.voanews.com/africa/cameroonsseparatists-intensify-attacks-protest-dialogue

Martin, B. (2007). Activism, social and political. In Gary L. Anderson and Kathryn G. Herr (eds.), Encyclopedia of Activism and Social Justice. Thousand Oaks, CA: Sage, pp. 19-27. Retrieved from https://www.bmartin.cc/pubs/07Anderson.html

Newby, P.K., Tucker, K. L. (2004). Empirically derived eating patterns using factor or cluster analysis: A Review. Nutrition Reviews, 62 (5), pp. 177-203. Retrieved from https://academic.oup.com/nutritionreviews/article/62/5/177/1860851

Okereke, C. N. (2018). Analysis Cameroon's Anglophone Crisis. Counter Terrorist Trends and Analyses,10 (3), pp. 8-12. International Centre for Political Violence and Terrorism Research, Retrieved from https://www.jstor.org/stable/26380430?seq=1\#metadata_info_tab_contents

The World Bank in Cameroon. (2018). Retrieved from https://www.worldbank.org/en/country/cameroon

The Commonwealth. (2019). Cameroon: History. Retrieved from https://thecommonwealth.org/our-member-countries/cameroon/history

Walton, J. (2013). The Tale of Two College Experiences: A Cluster Analysis of Obama's Argument for Higher Education Reform. Administrative Issues Journal, 3(3), https://dc.swosu.edu/aij/vol3/iss3/16.

Weaver, R. (1953). The Ethics of Rhetoric. Henry Regnery Company. 
Zerba, M. L. (1990). Aristotle's Rhetoric: Theory, Truth and Metarhetoric. UC Berkeley Cabinet of the Muses: Rosenmeyer Festschrift. Retrieved from

https://escholarship.org/content/qt3mt6v449/qt3mt6v449.pdf?t=lnqtts 